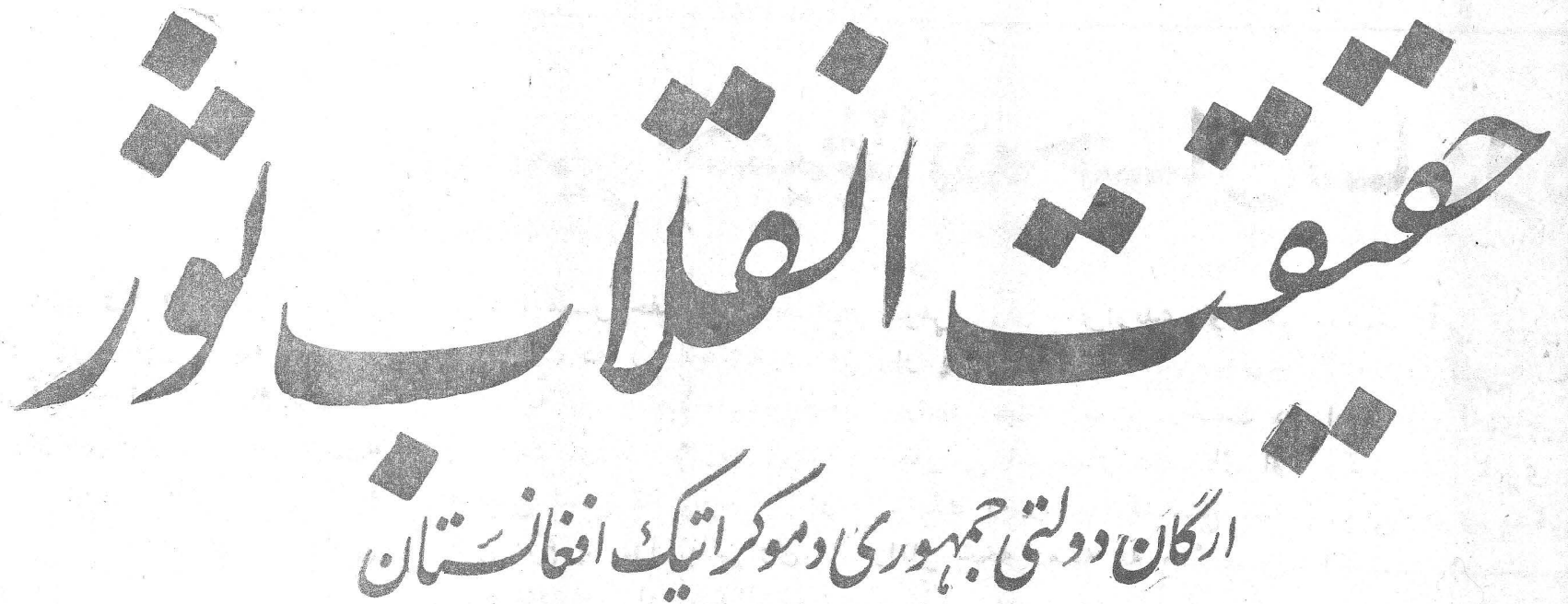

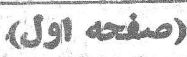

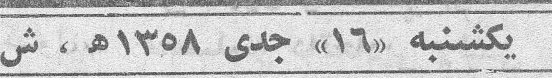

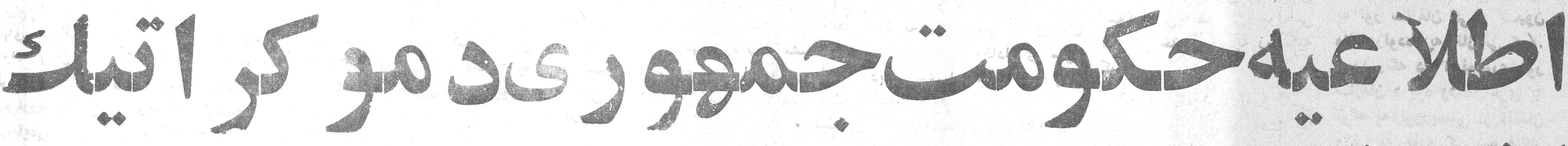

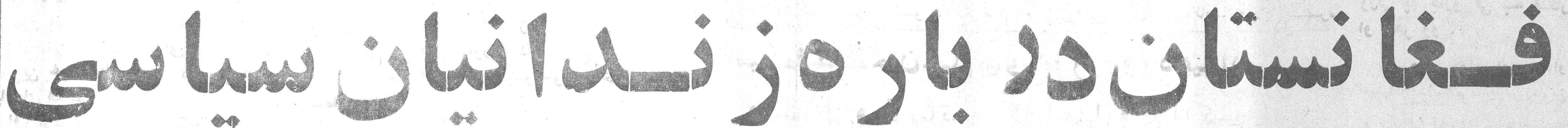

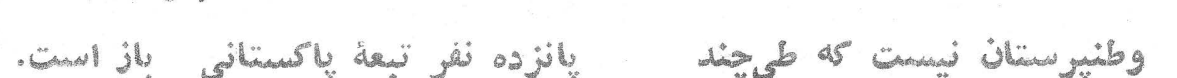

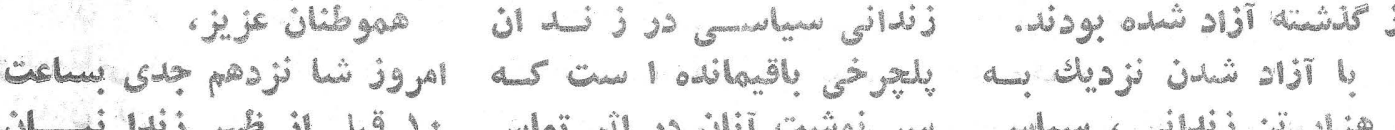

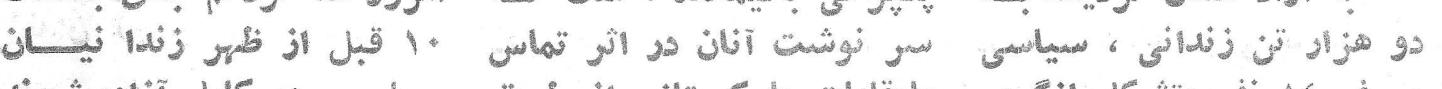

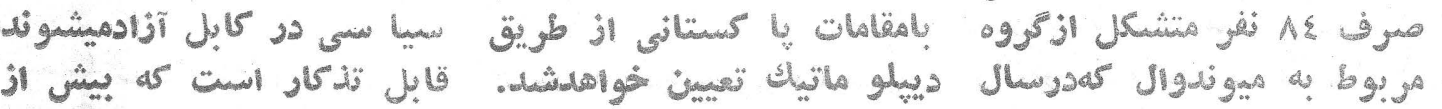

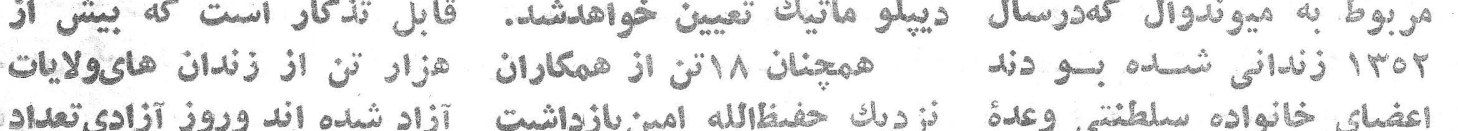

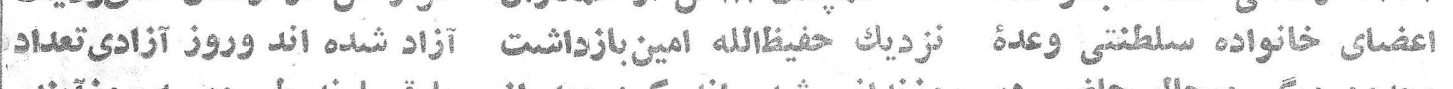

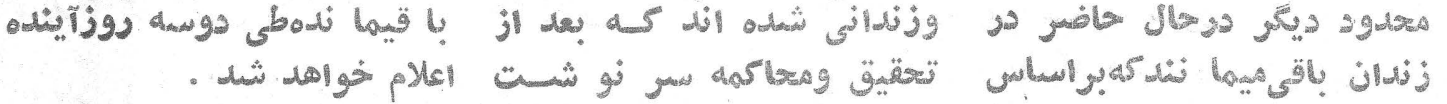

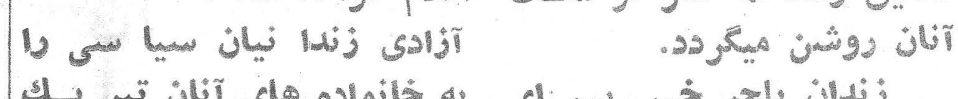

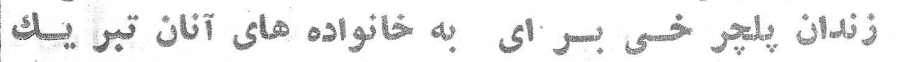

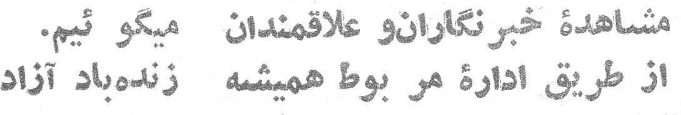

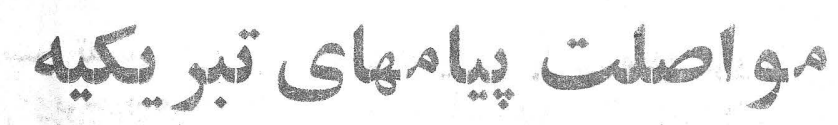

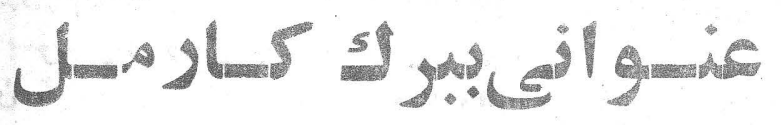

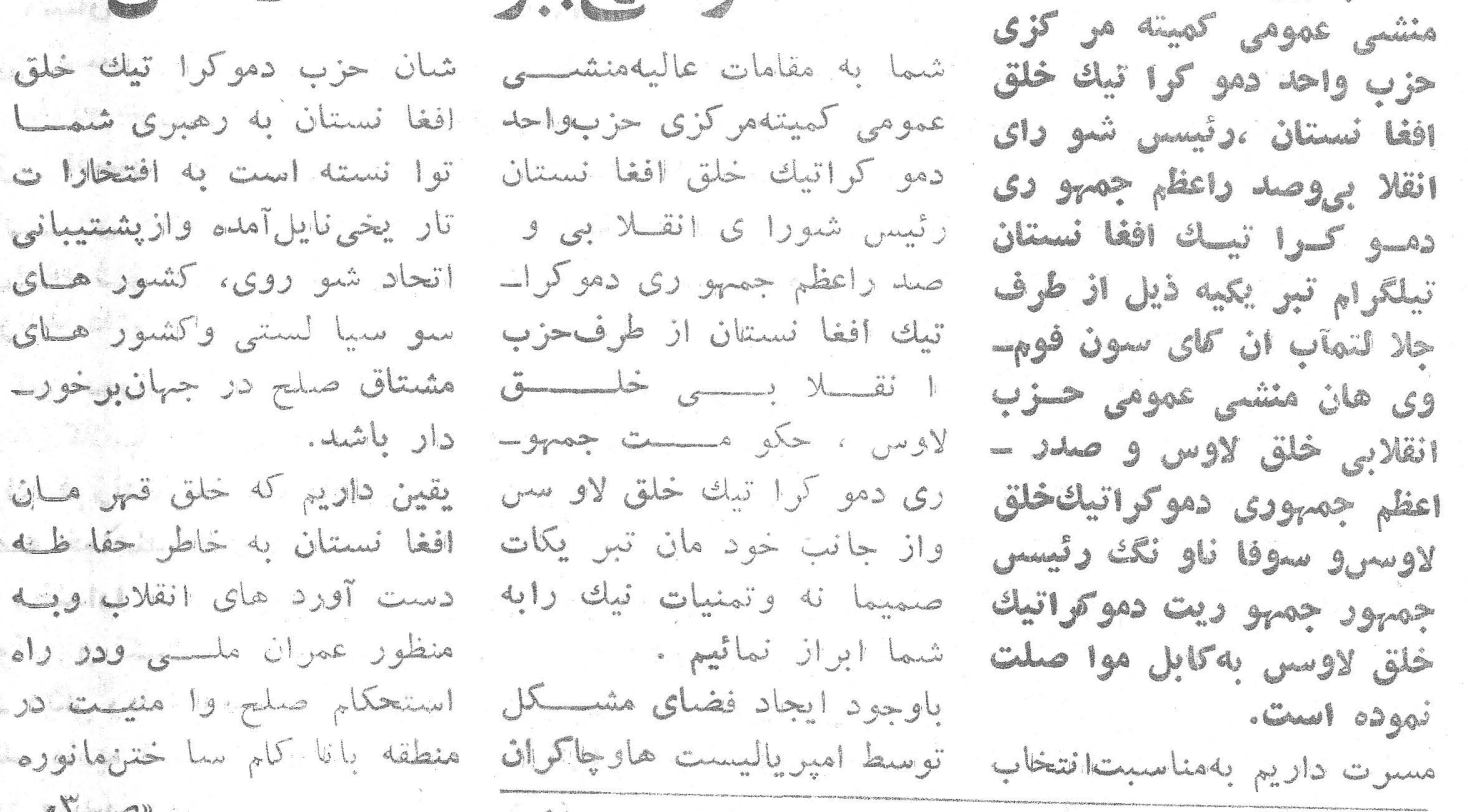

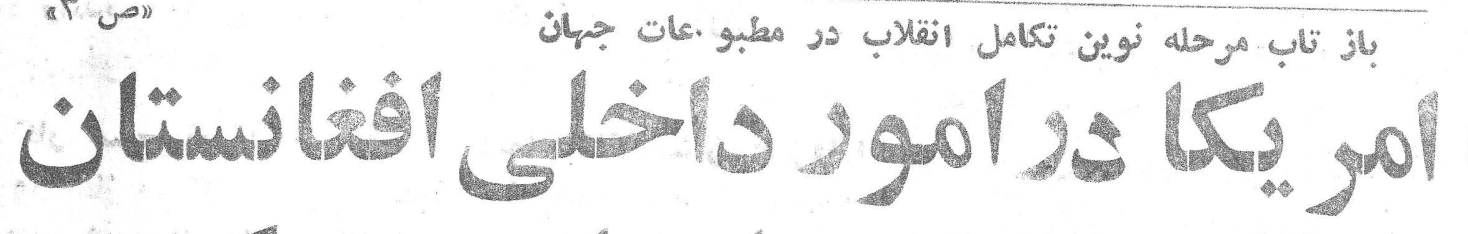

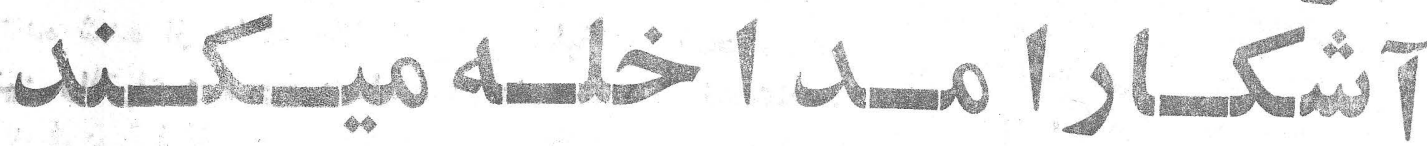
wines:

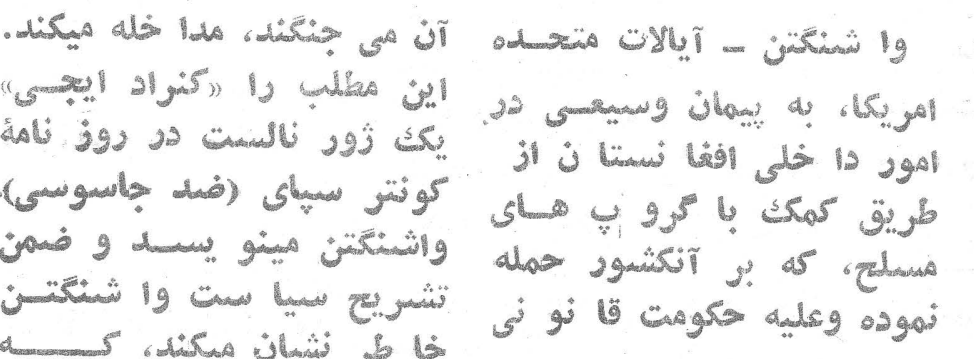

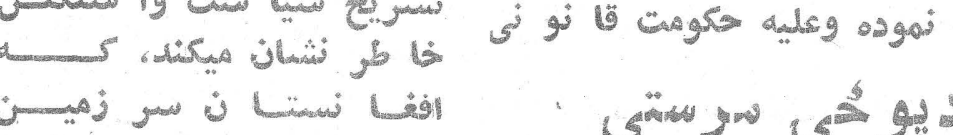

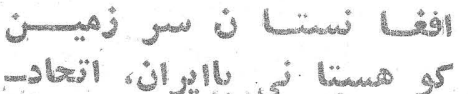

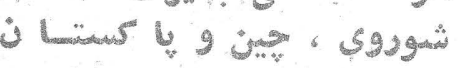

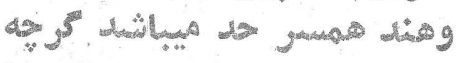

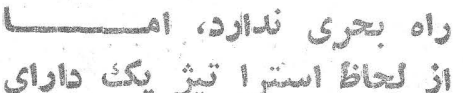

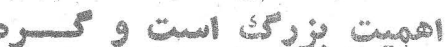

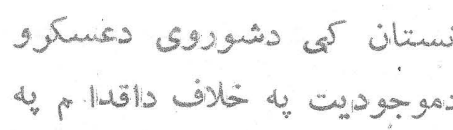

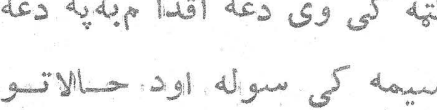

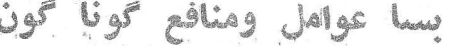

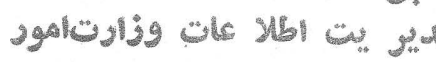

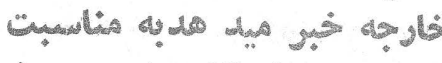

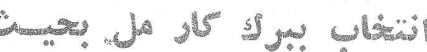

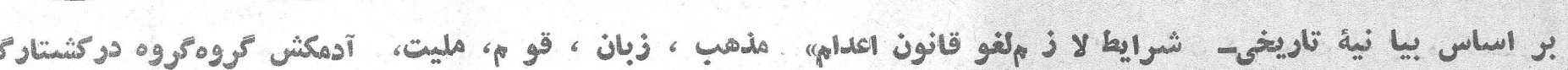

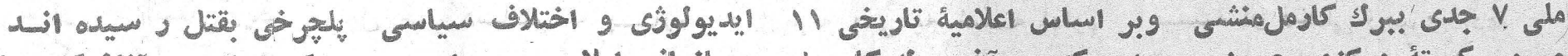

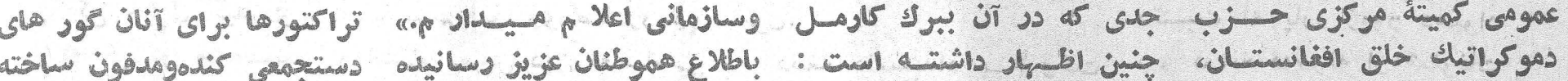

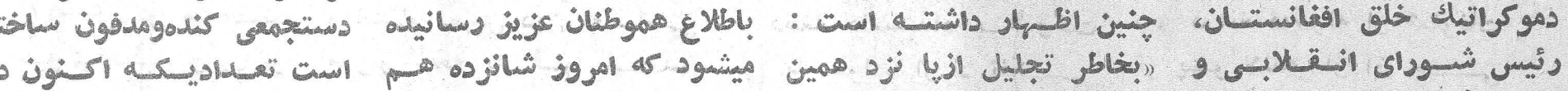

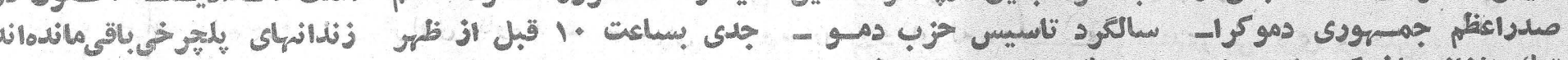

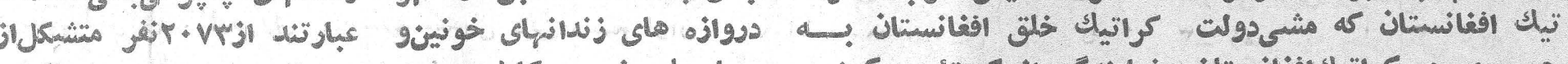

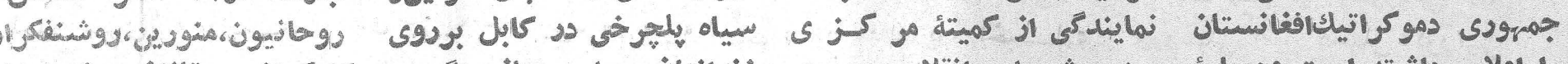

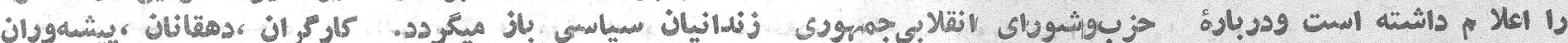

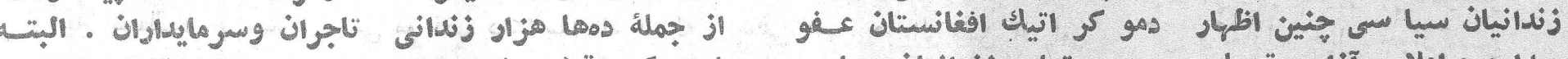

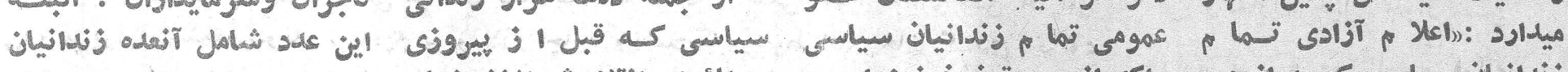

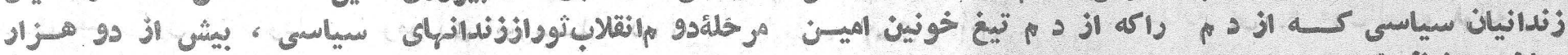

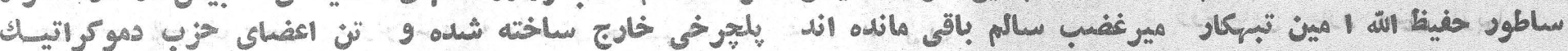

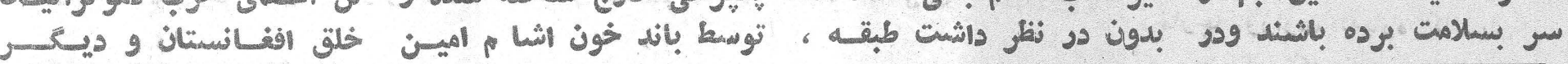

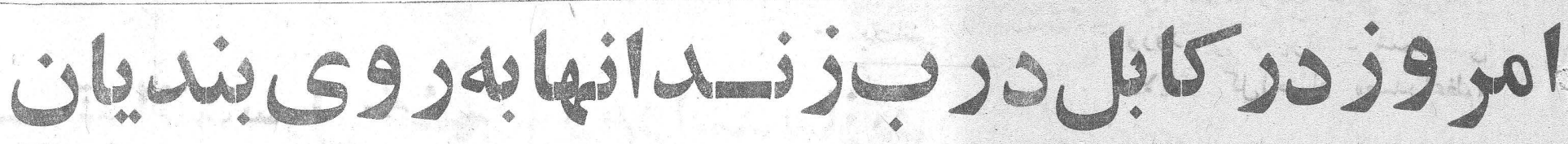

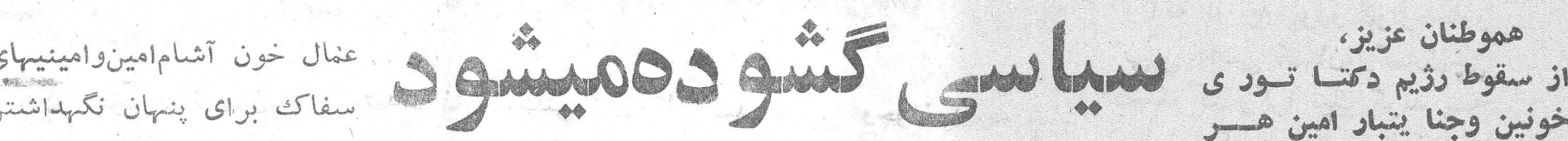

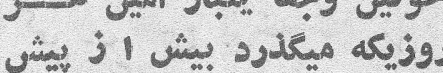

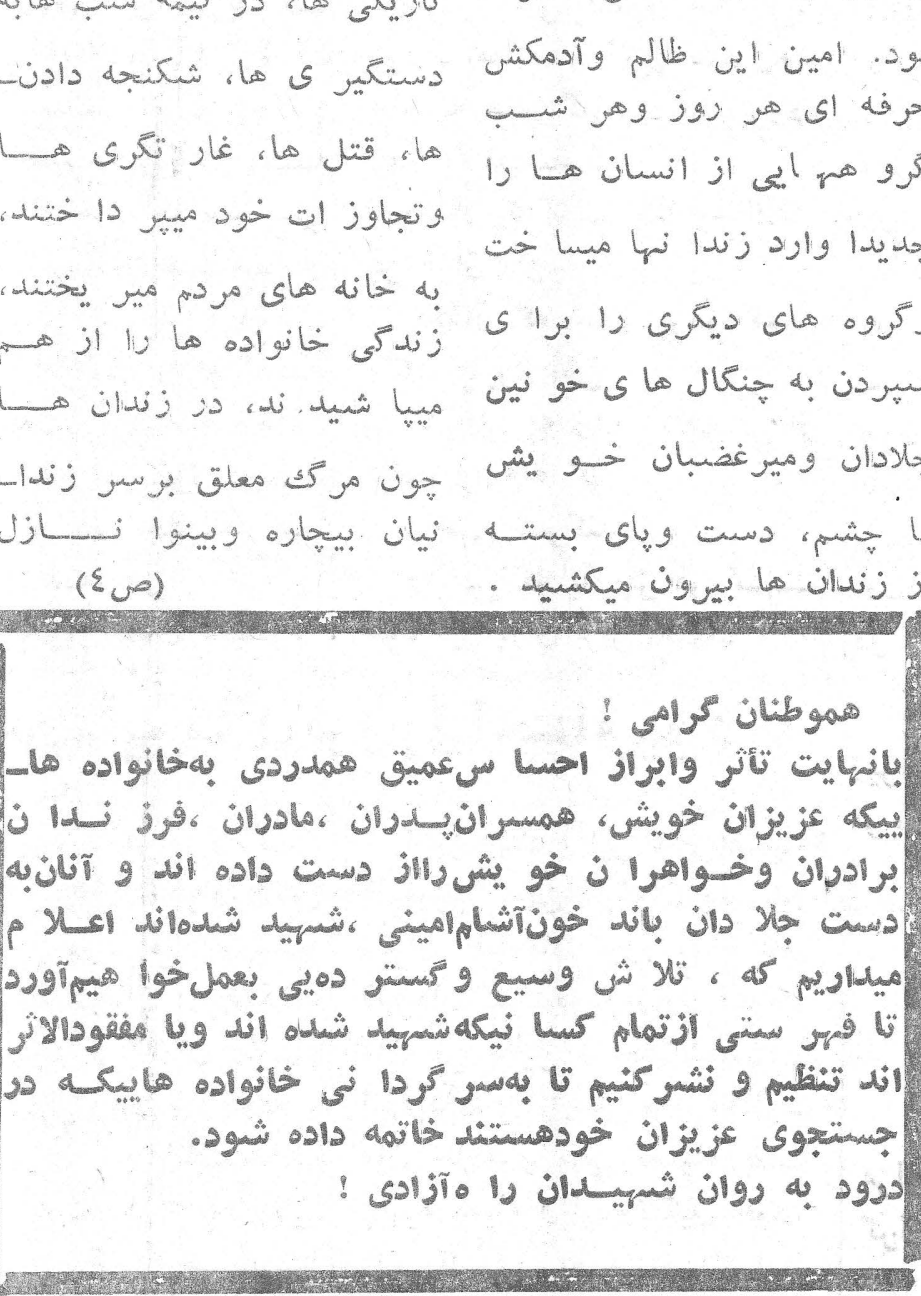

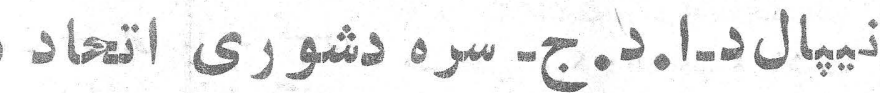

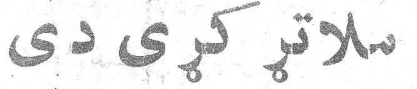

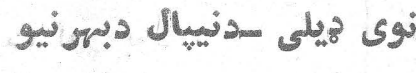

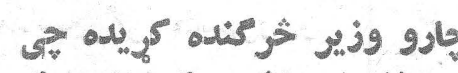

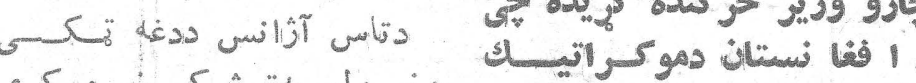

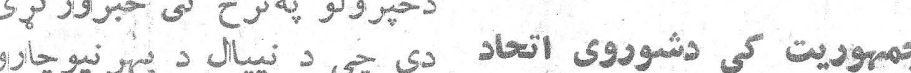

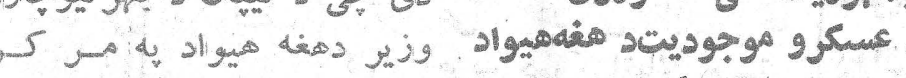

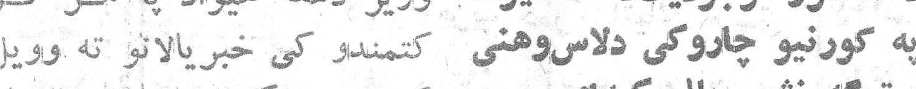

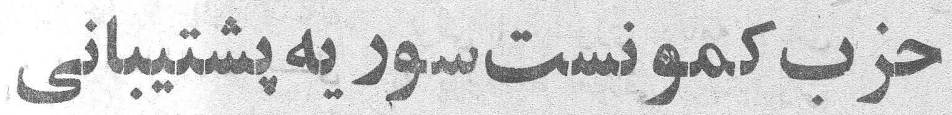

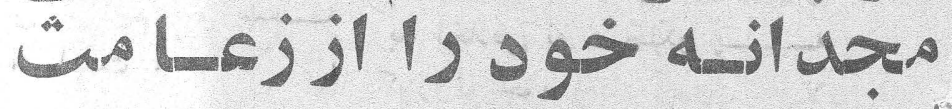

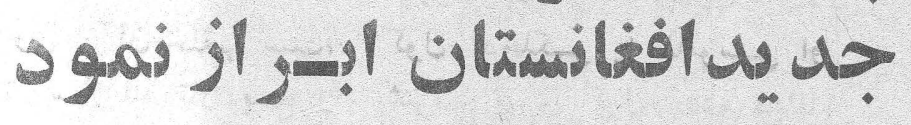

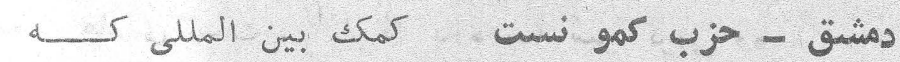

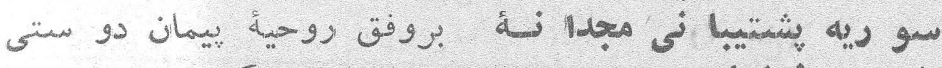

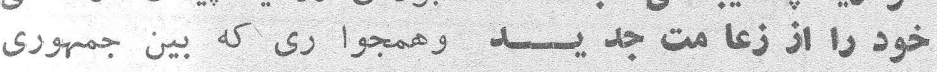

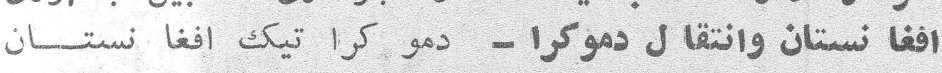

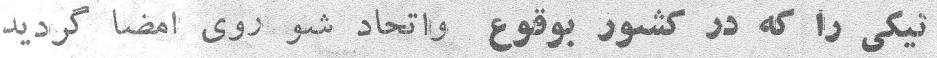

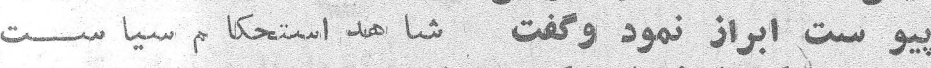

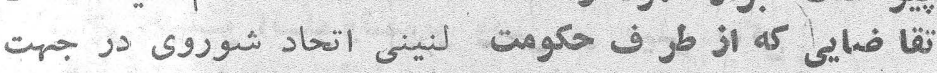

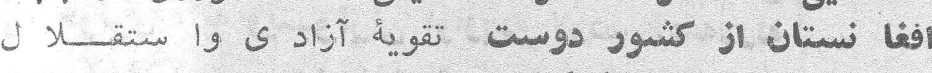

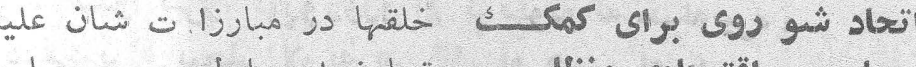

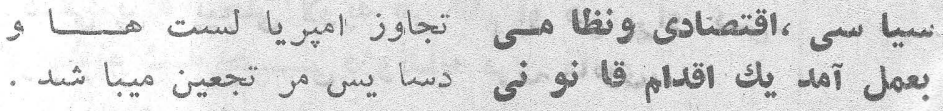

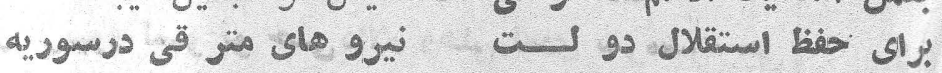

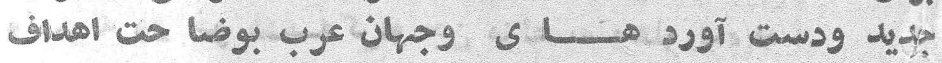

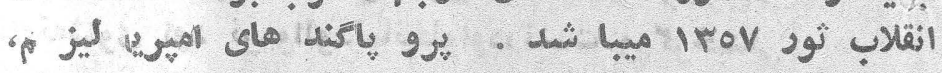

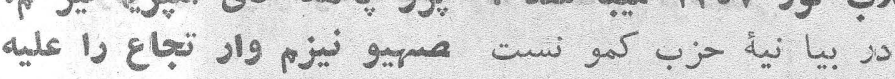

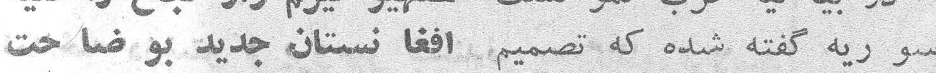

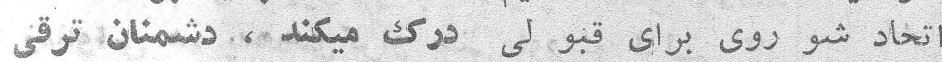

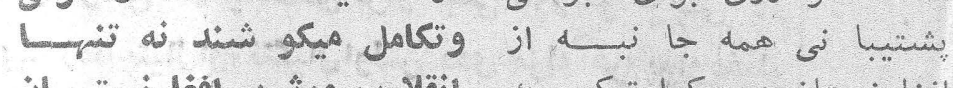

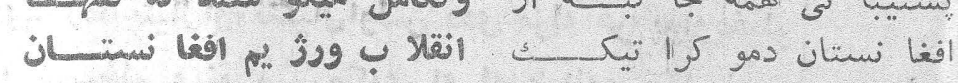

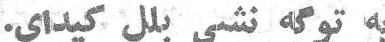




\section{دامير حفيظالههــاننـادودى}

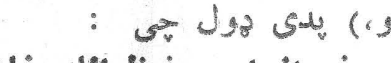

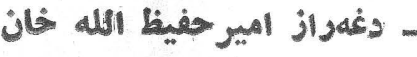

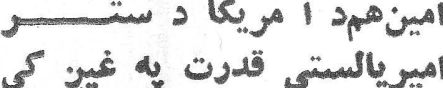

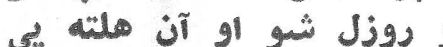

به خيل تود سياسى فعاليت

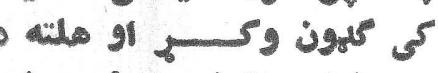

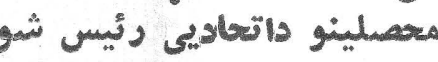

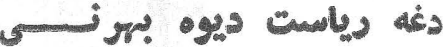

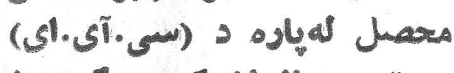

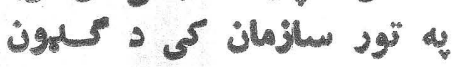

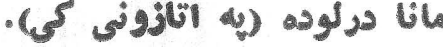

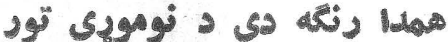

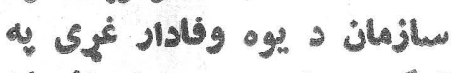

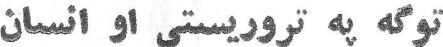

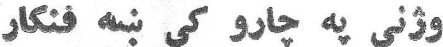

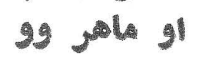

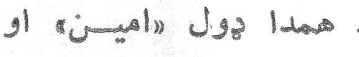

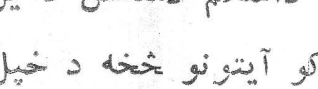

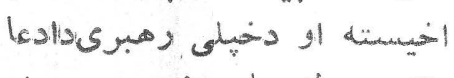

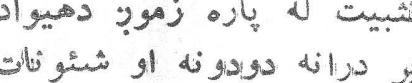

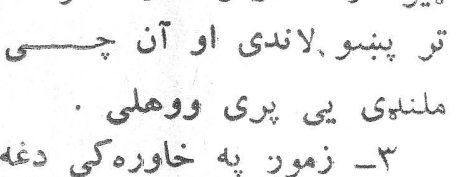

وزوستى امير دخبلى كورنسي

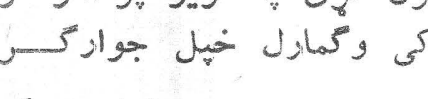

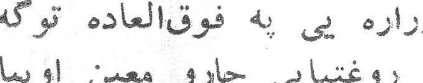

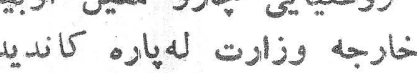

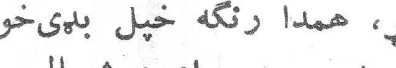

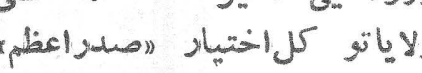

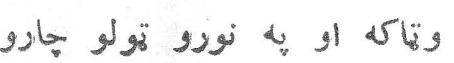

كمين داسى كسان وكمارلجيى

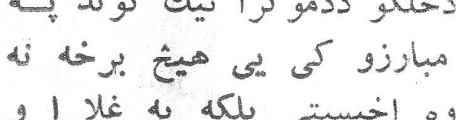

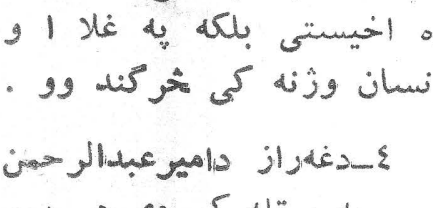

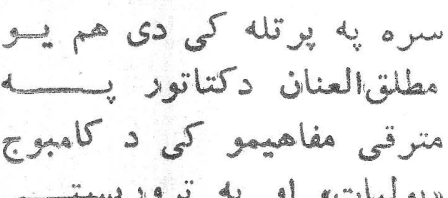

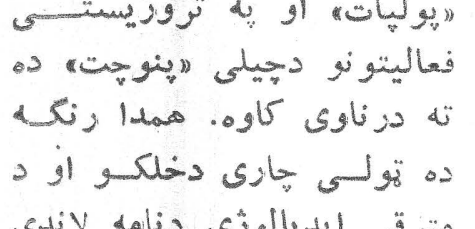

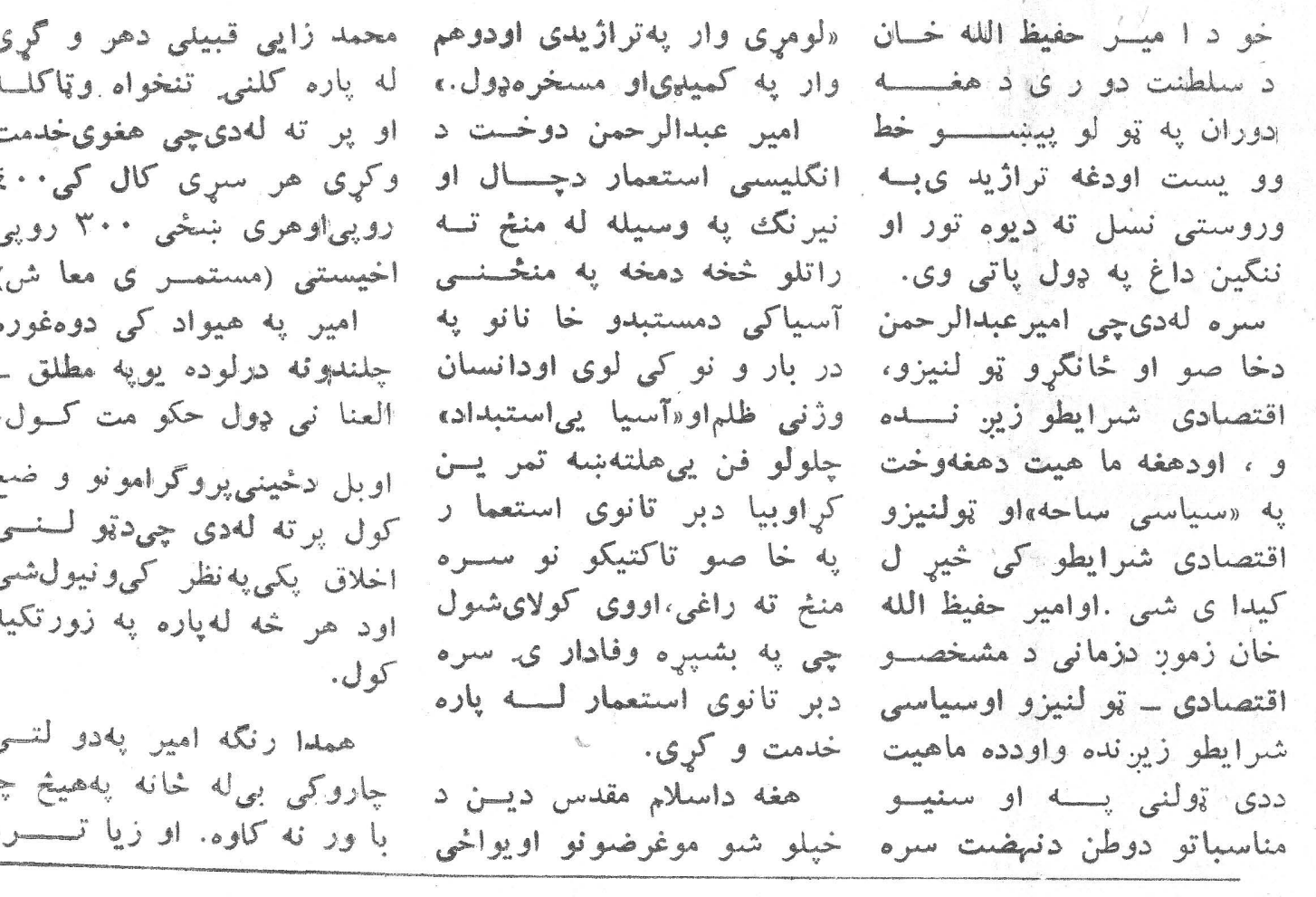

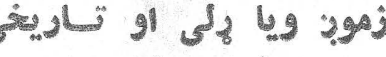

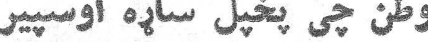

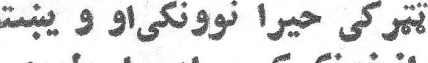

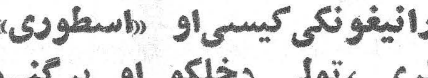

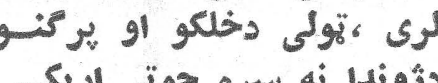

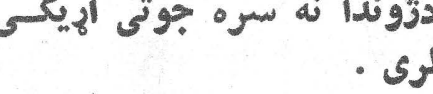

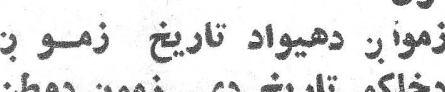

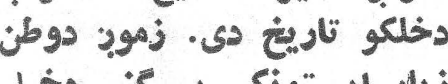

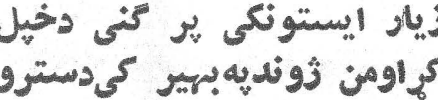

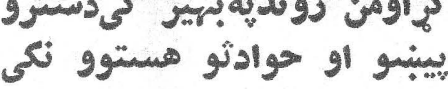
هي

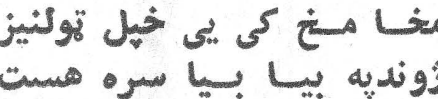

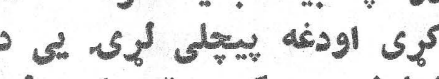

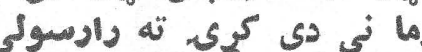

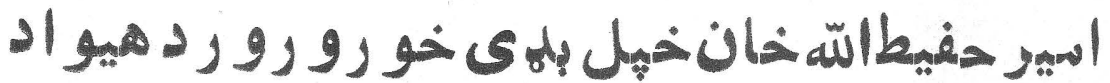

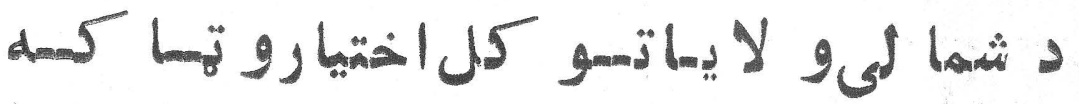

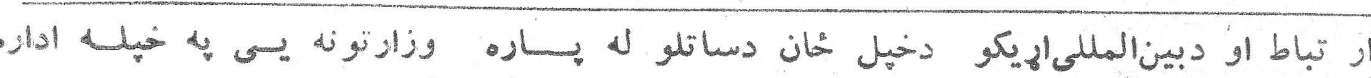

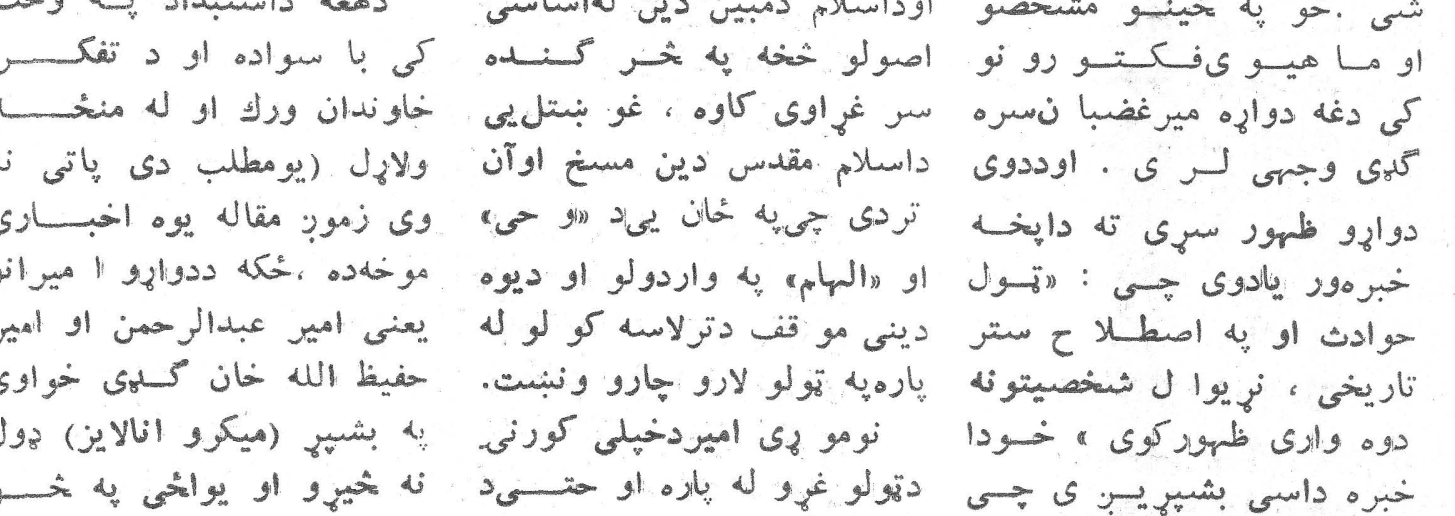
ح، بكتاش

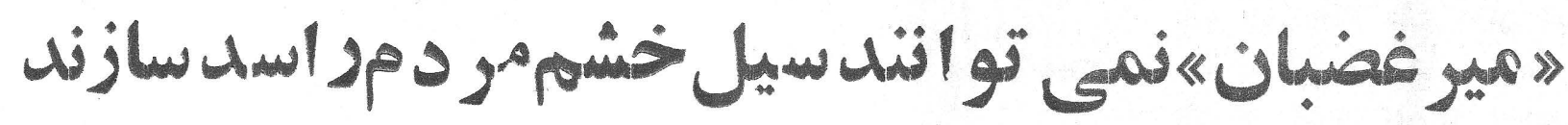

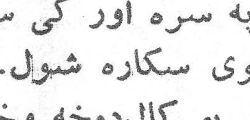

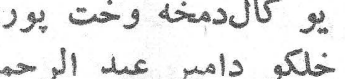

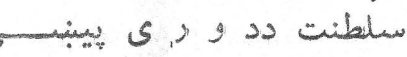

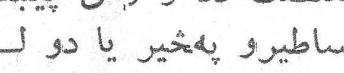

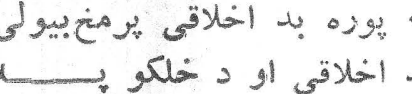

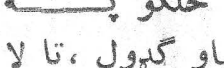

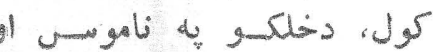

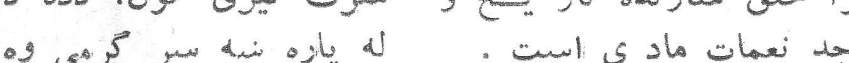
( ب)

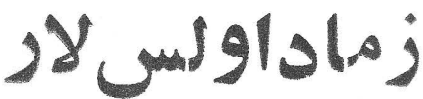

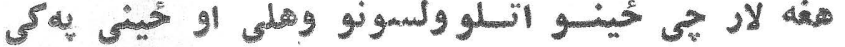

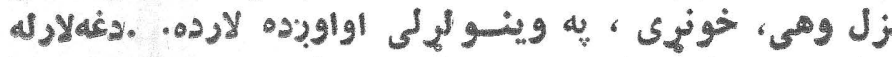

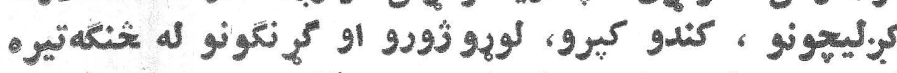

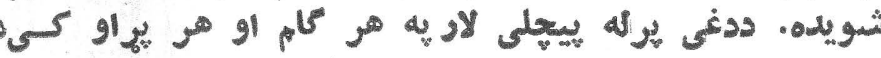

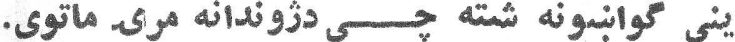

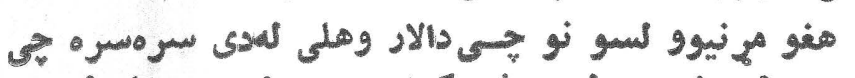

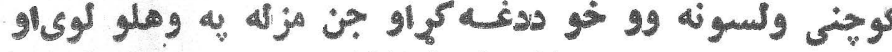

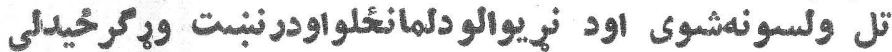

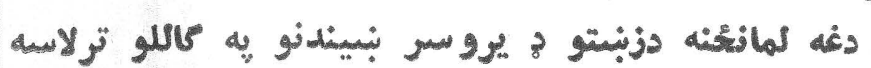

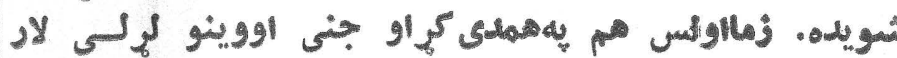

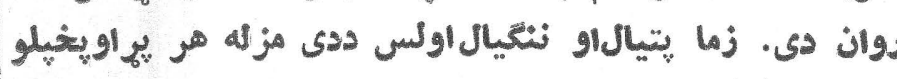

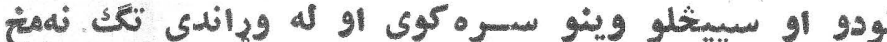

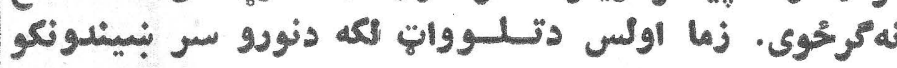

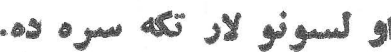

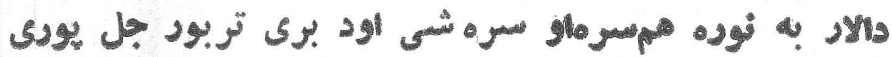
"نان

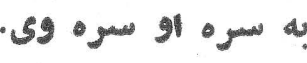

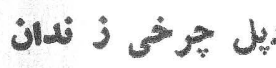
ironglg
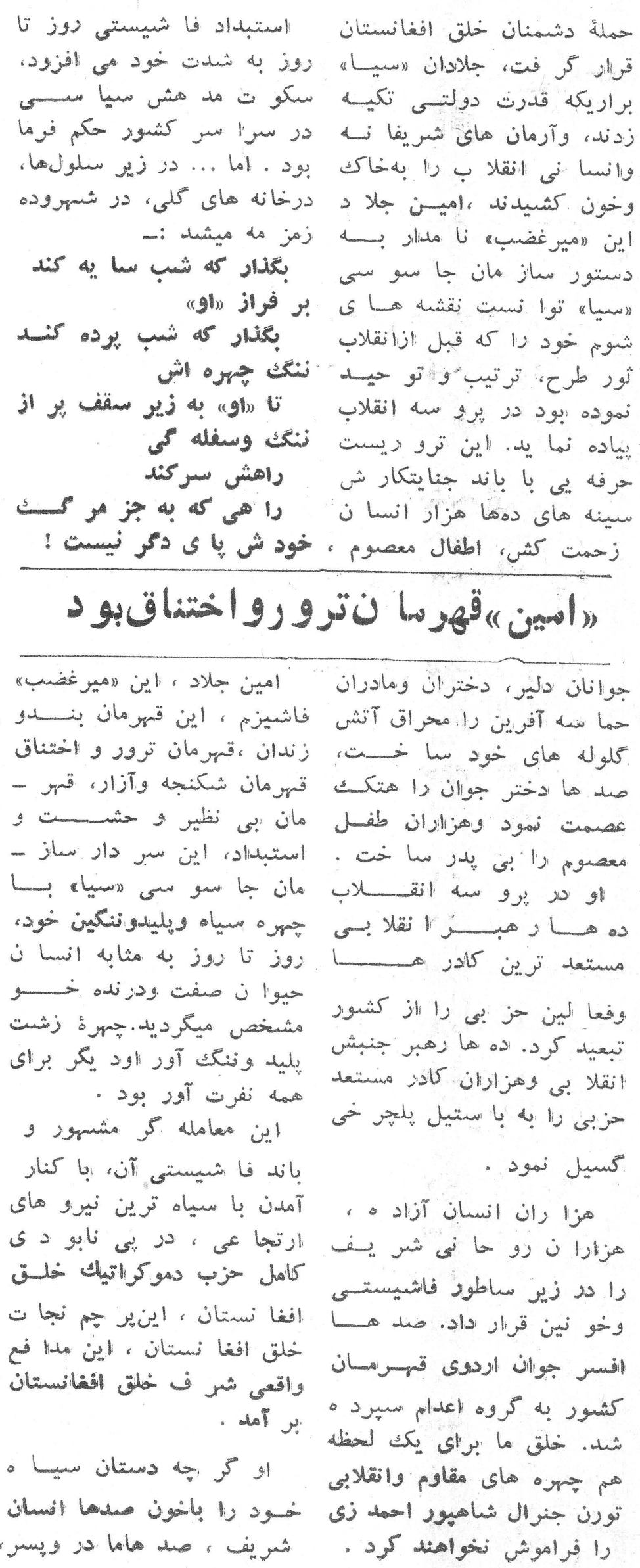

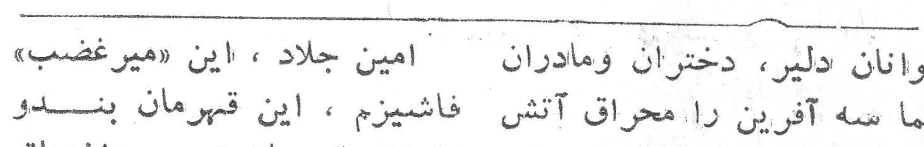

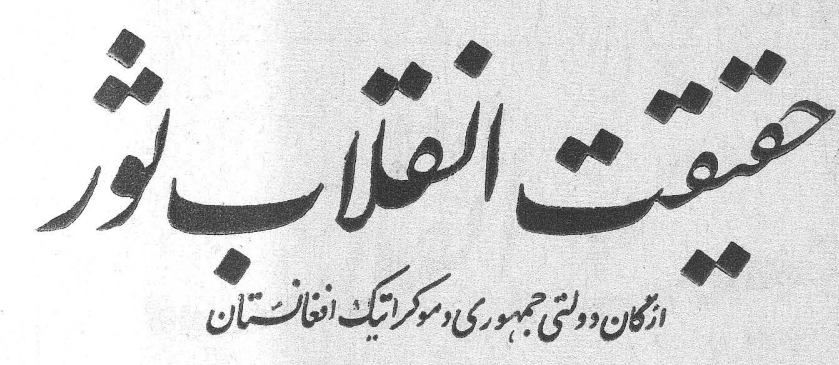

\section{زندهباد آزادى!}

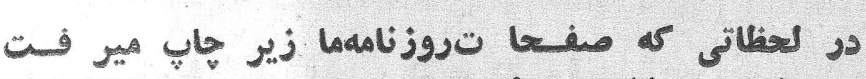

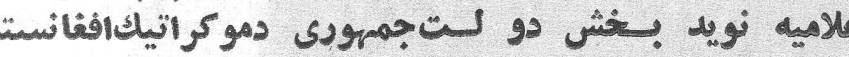

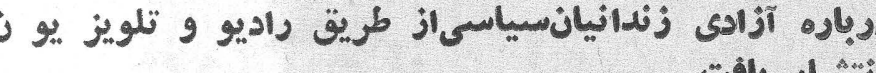

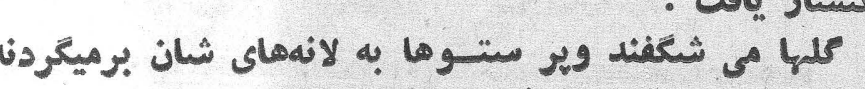

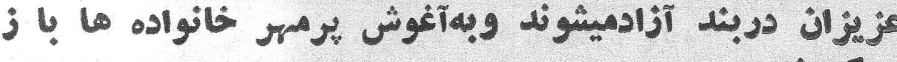

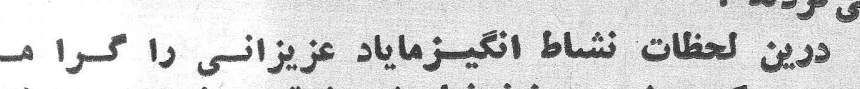

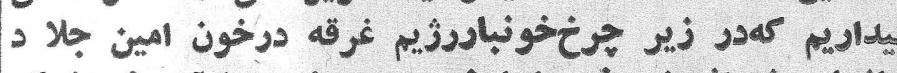

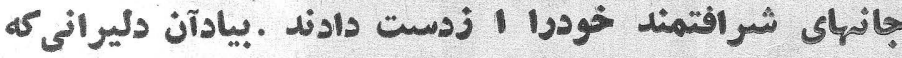

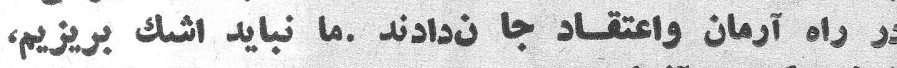

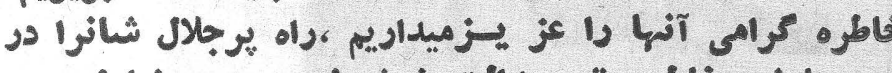

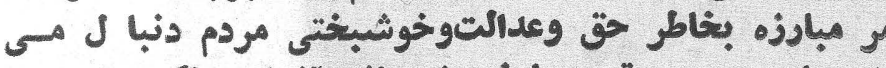

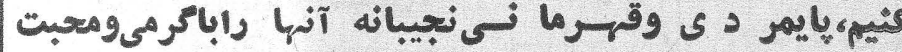

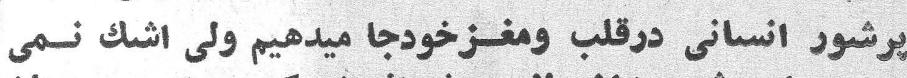

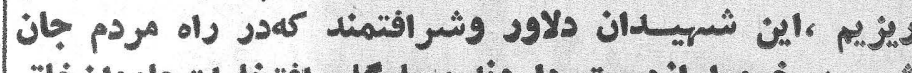

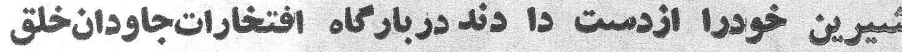

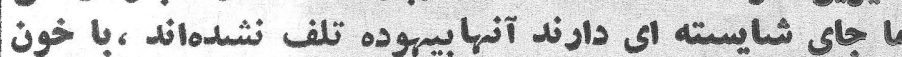

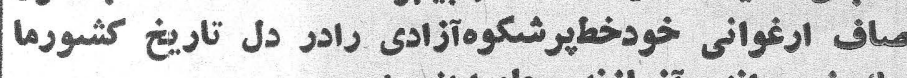

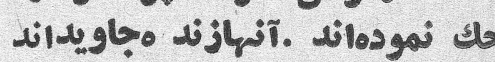

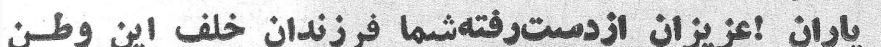

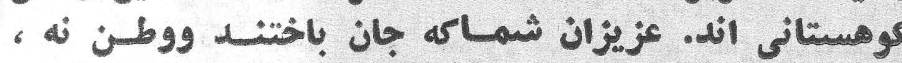

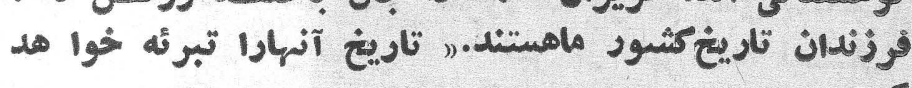
شهيدان راه وطن ،شهيدانوراه آذادى حاكميتملىو تماميت

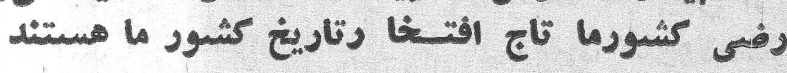

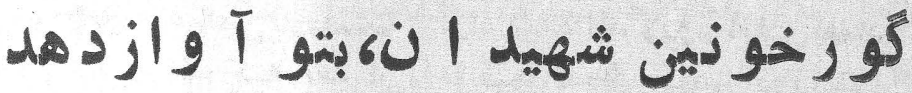

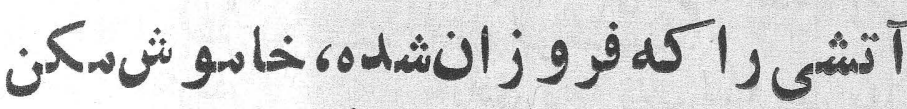

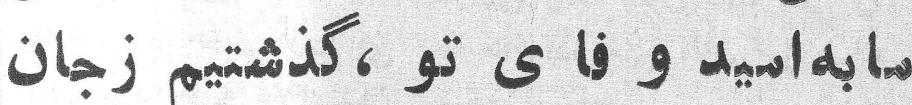

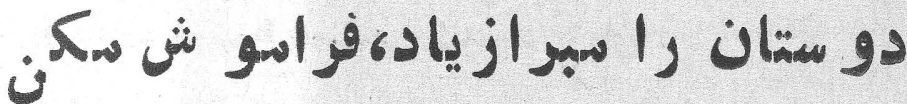
ماسر تعظيم دوبرابر كو رخونين شهيدان وطن فرو د مي

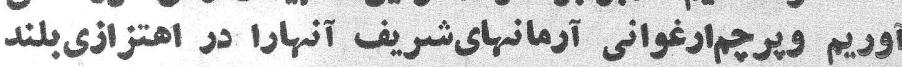

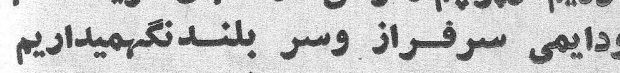

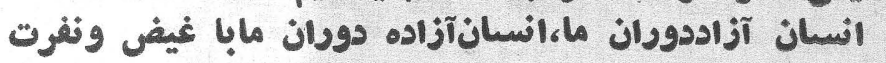

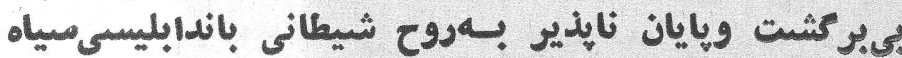

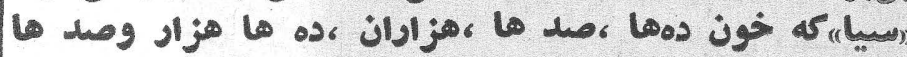

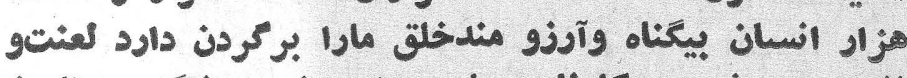

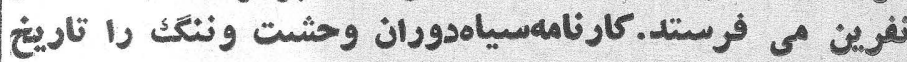

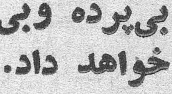

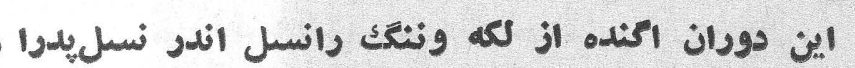

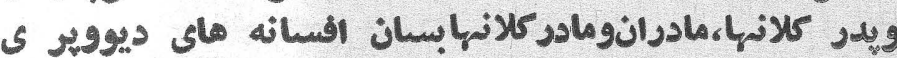

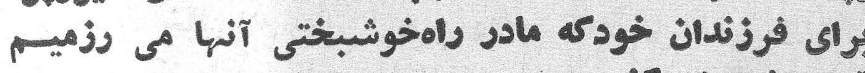

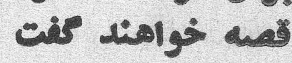

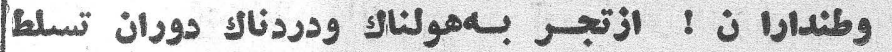

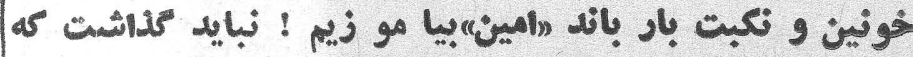

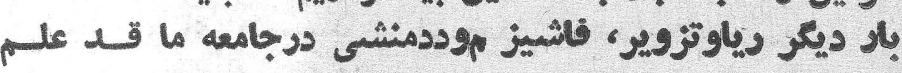

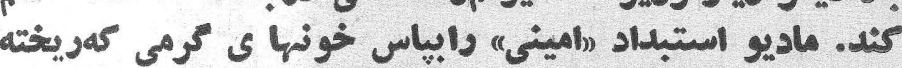

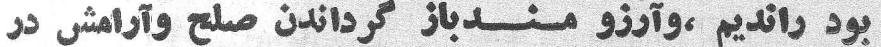

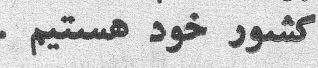

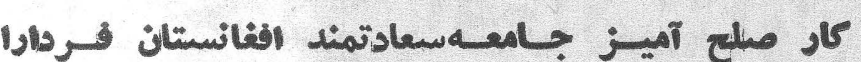

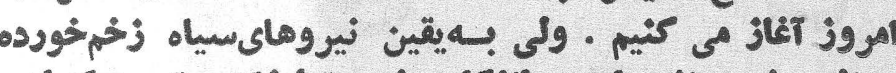

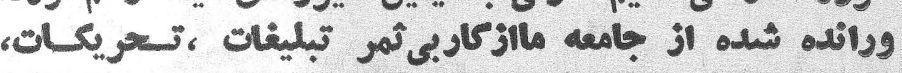

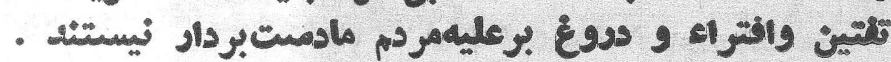

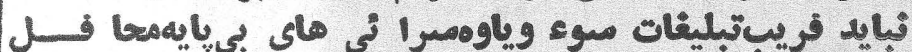

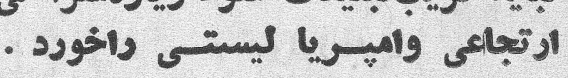

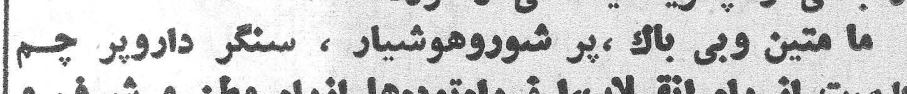

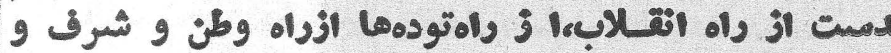

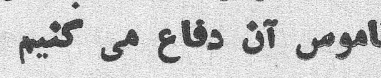

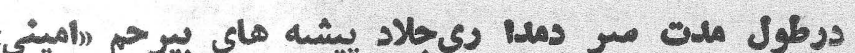

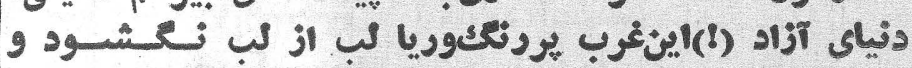

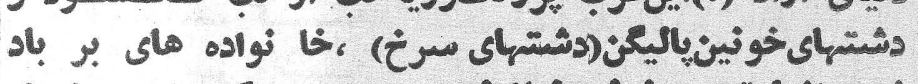

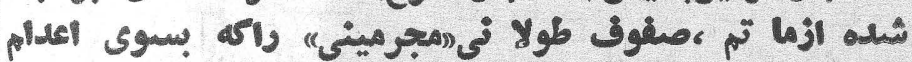

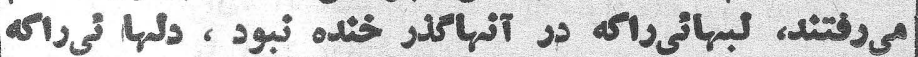

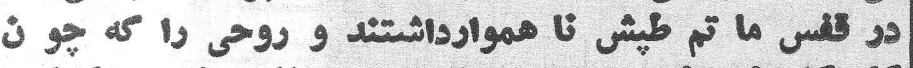

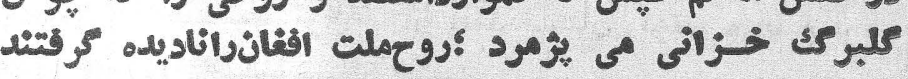

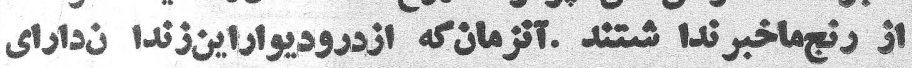

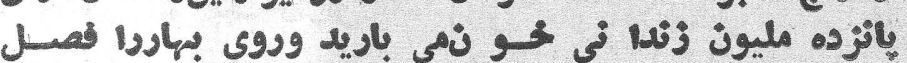

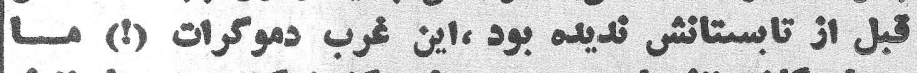

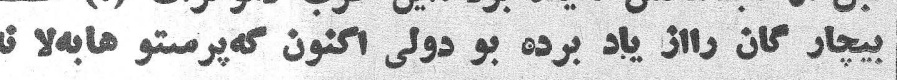

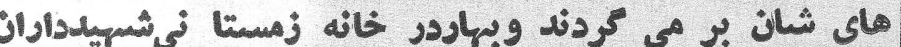

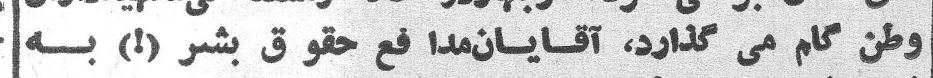

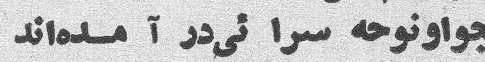

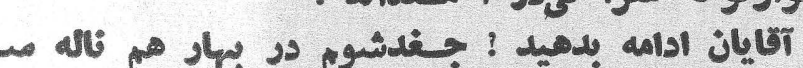

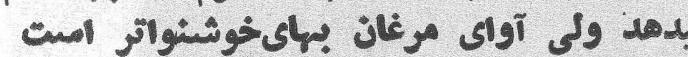

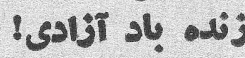




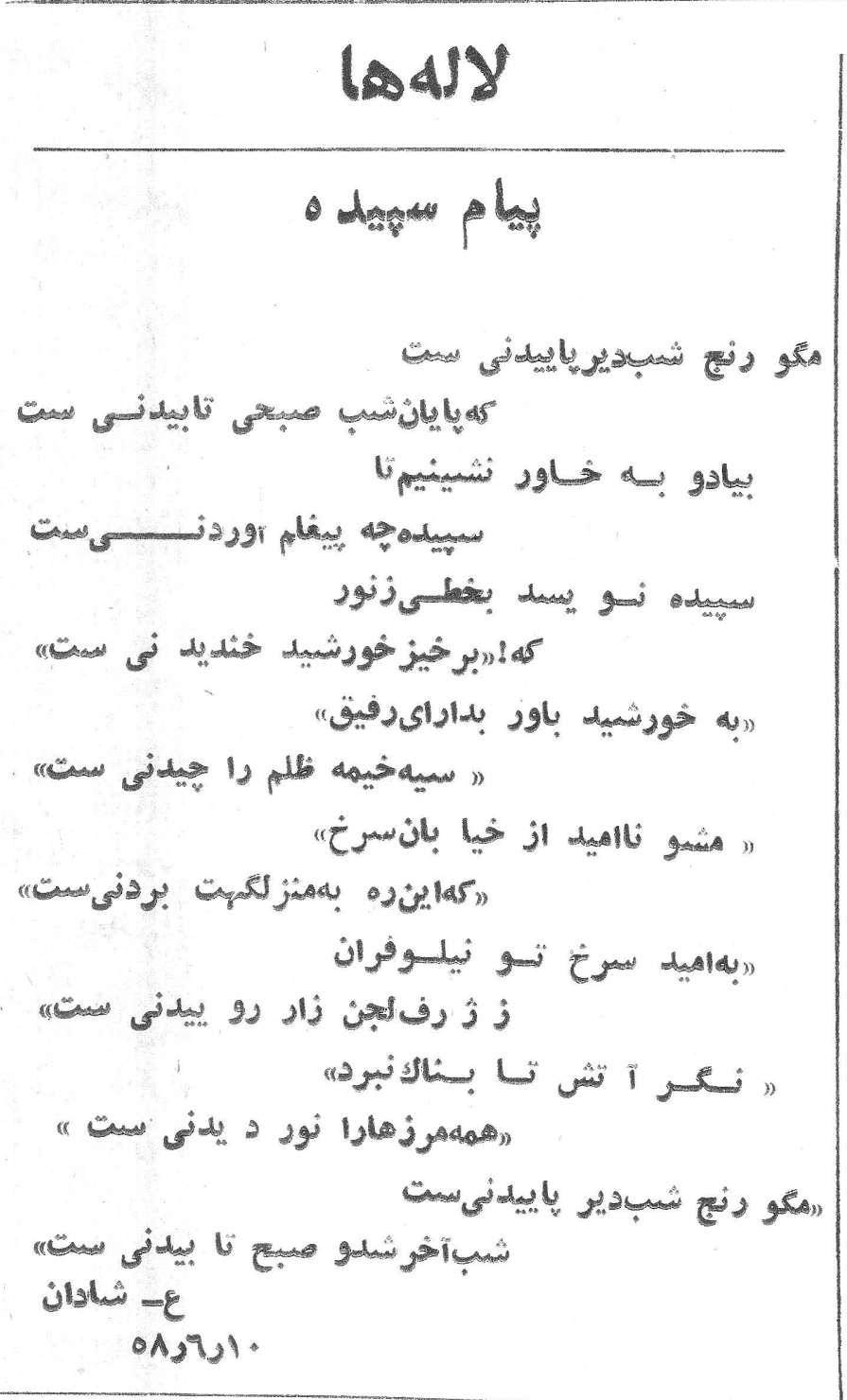

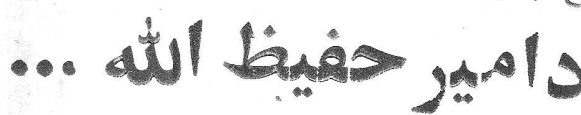

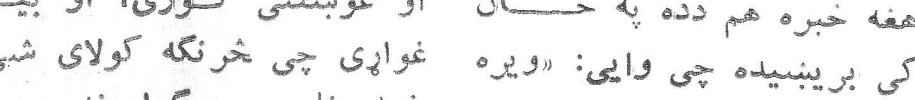

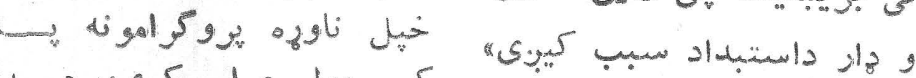

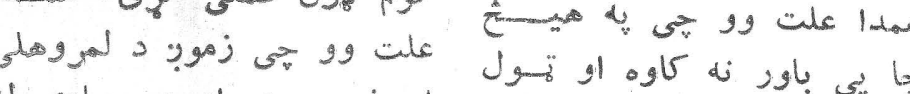

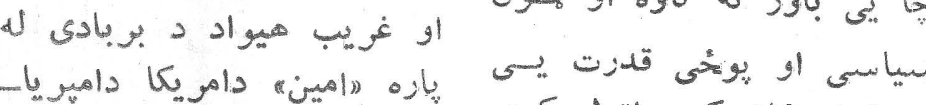

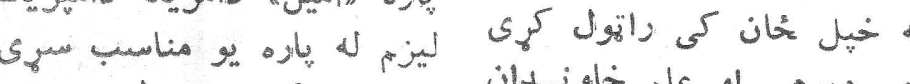

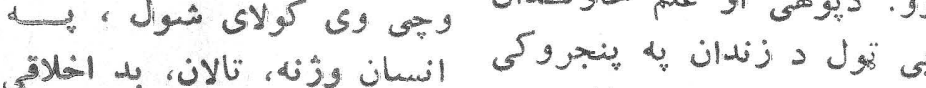

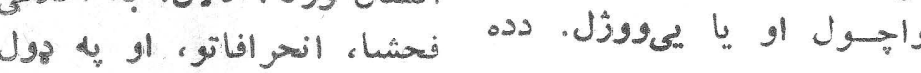

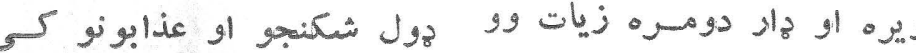

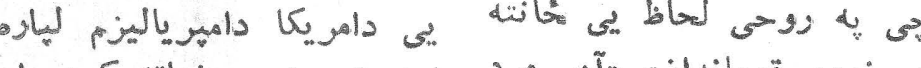

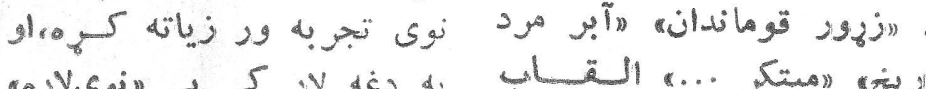

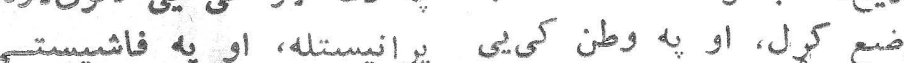

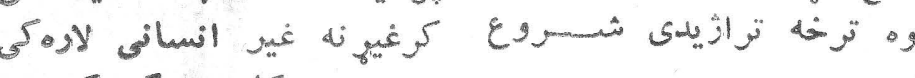

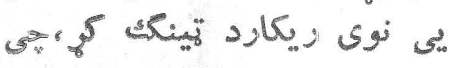

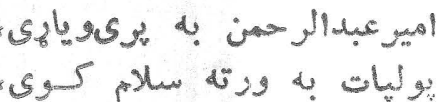

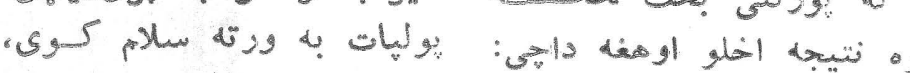

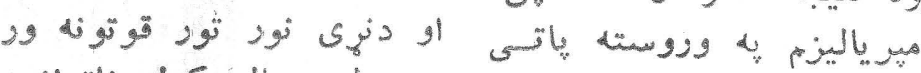

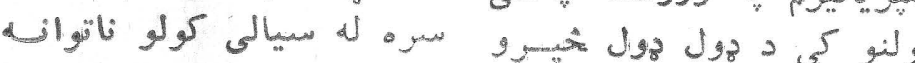

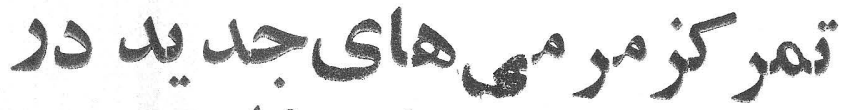

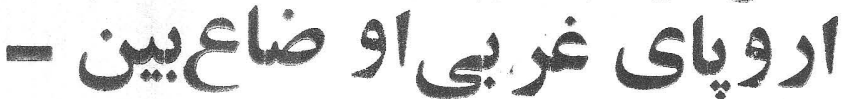

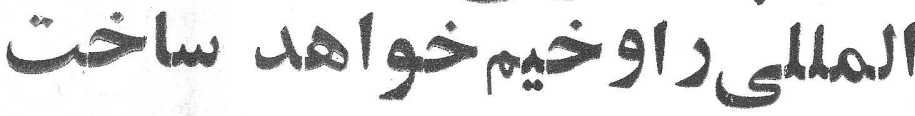

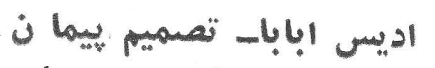

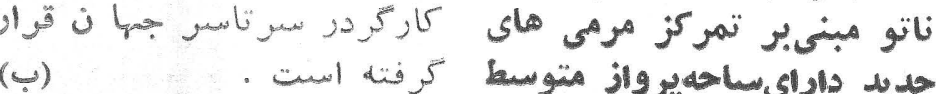

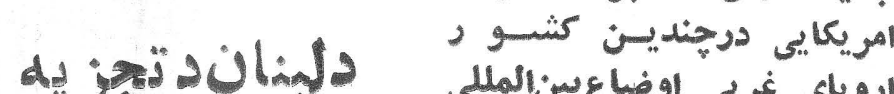

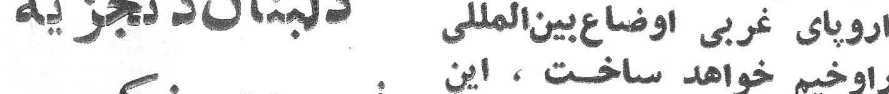

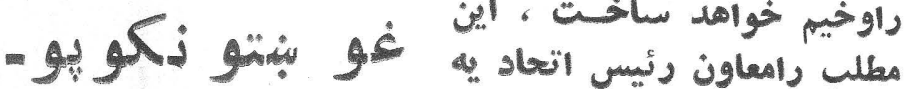

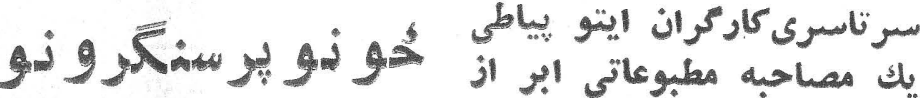
ن

مينولا- دفلسطينيا نو او هو

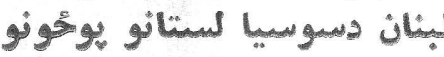

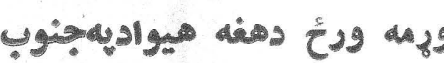

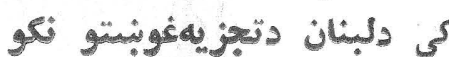

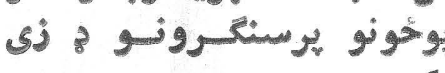
وكئ.

\section{اوخو است با كثــتن و بستن اند يشمنـدان

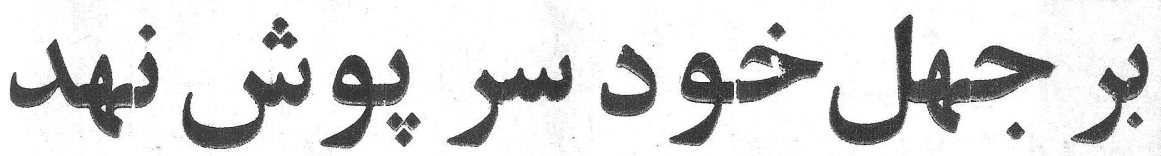

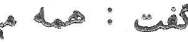

المين عقدة: زادا ذقى دابشت

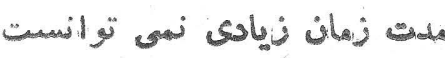

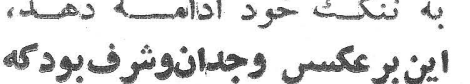

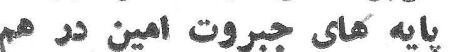

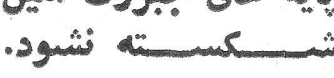

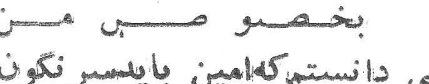

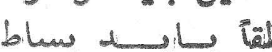

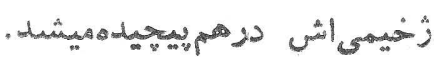

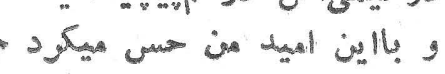

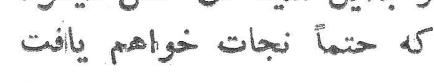

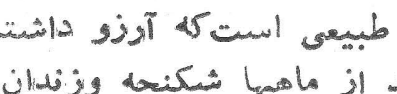

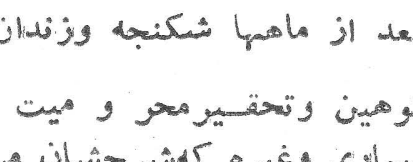

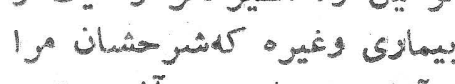

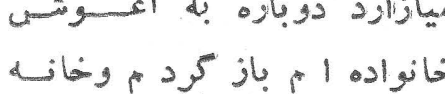

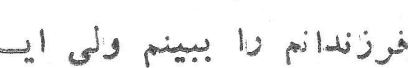

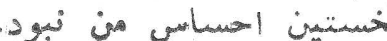

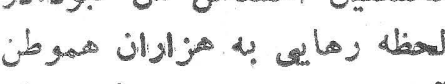

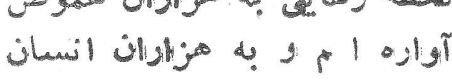

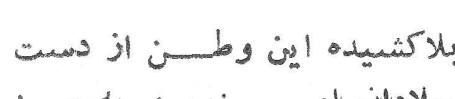

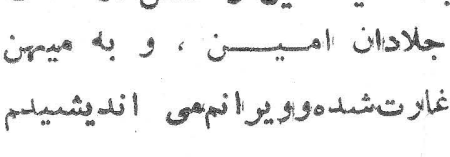

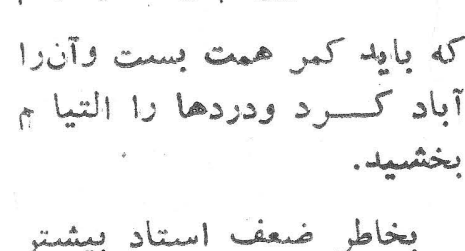

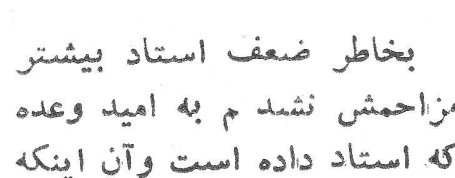

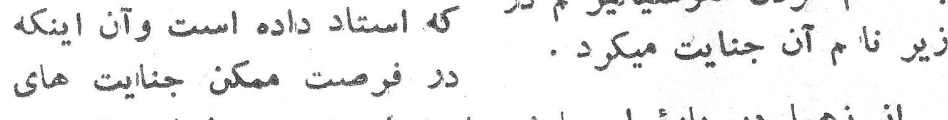

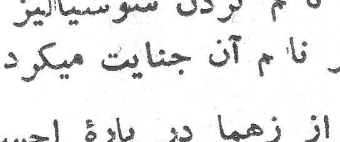

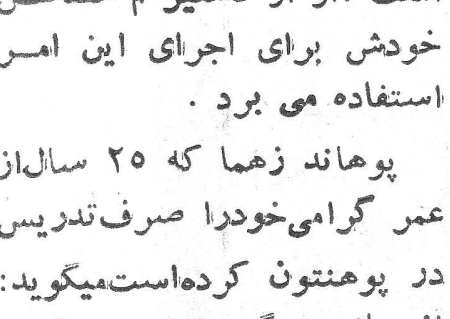

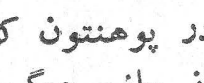

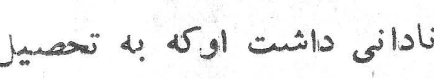

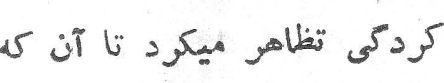

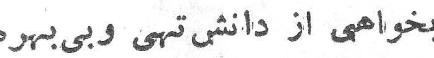

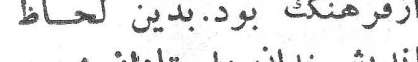

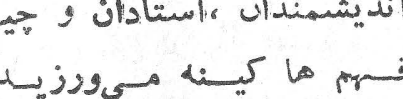

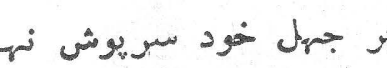

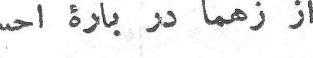

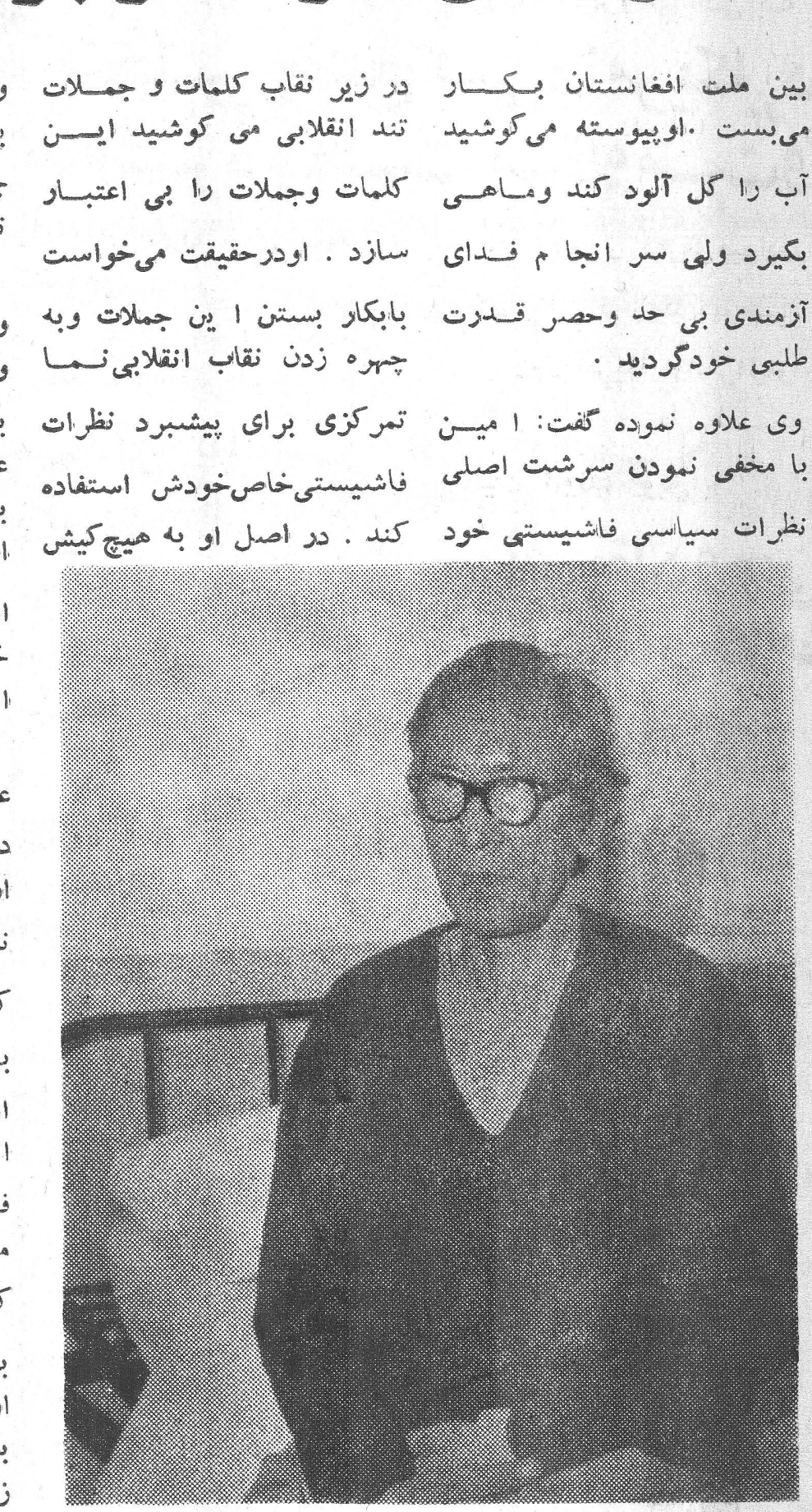

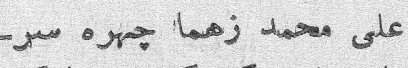

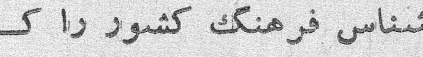
ثازه ازشكنجه كاه جلاداناميني

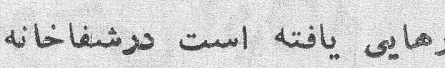

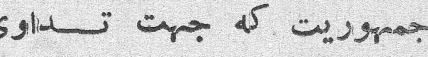

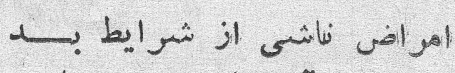

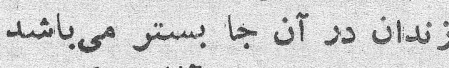

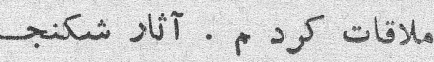

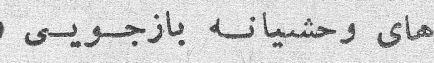

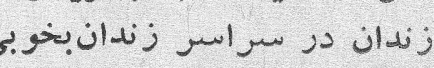

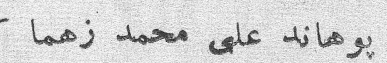

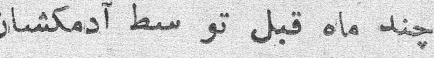

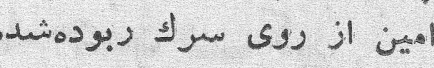
وبعد از شكنجه هاى وحشيانه

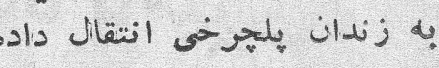
شد در بارة سرشت وند وماهيت

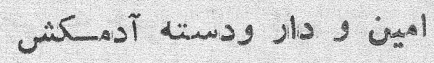
جنايتكار اومى كو يد :أميس ودئ از نظر روانى بيك ميكالوهينيك ويك ديوانه خود خراه بود كيكالومنيك

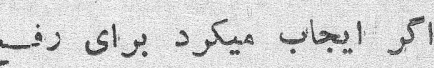
عطلش خود خواهى وزيكرد برسيدنبي

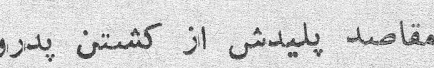

هادر خود نيزدزيغ نميكرد.

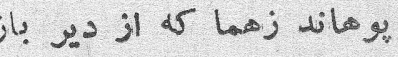

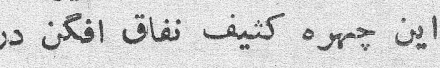
درون نهضت و ملت افغانستان را مىشناخت در بارة حقيقت

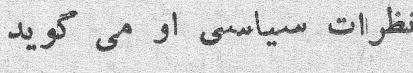

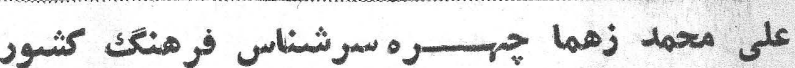

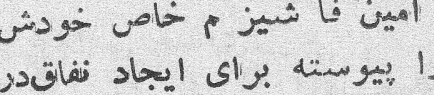

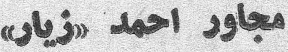

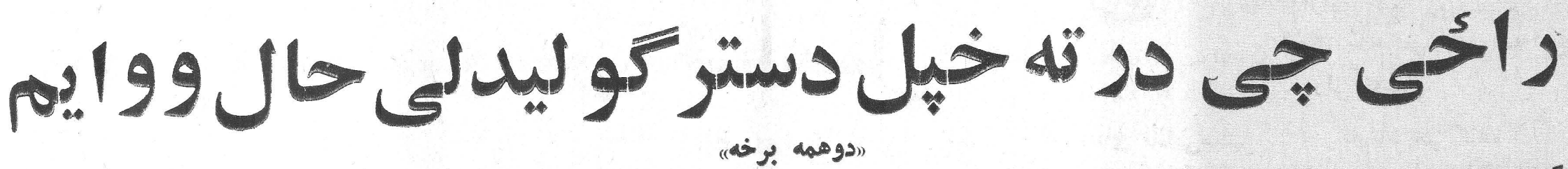
داشته است مكاحته

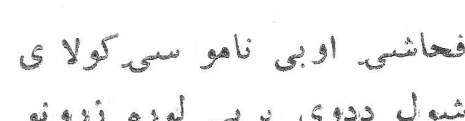

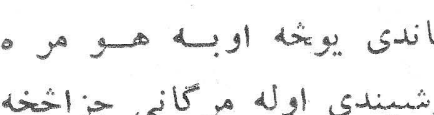

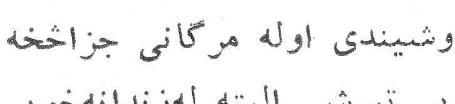

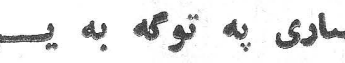

جيرى كميتومى كورن.

(كودال) ته وليزدول شو، او، باله او داسى نودى خندى او

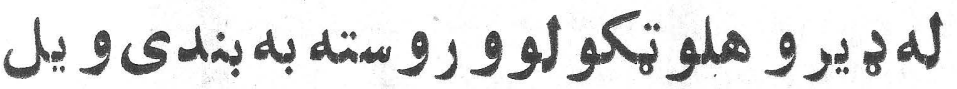

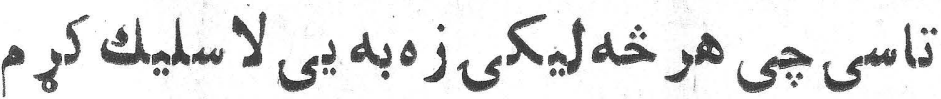

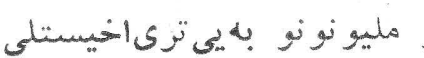

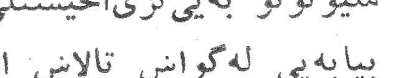

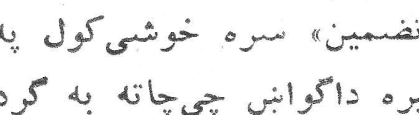

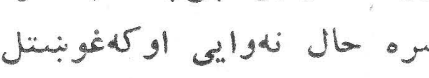

لهيبي جيى اكساوزته بيخى ونه

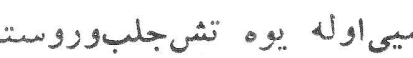

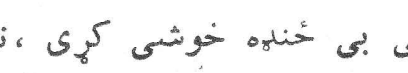

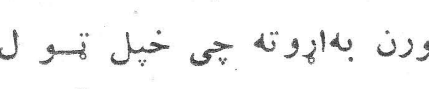

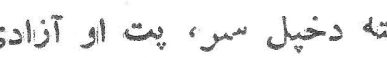

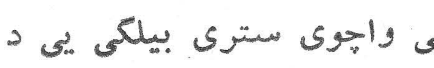

(بقيه صاول) (بقاول)

...

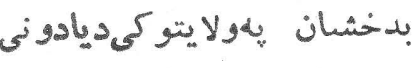

وار دى خي دعبداللهامينغوندي

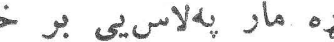

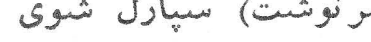

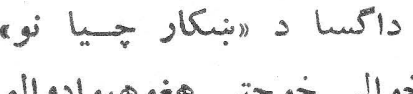

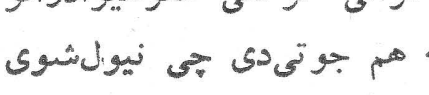

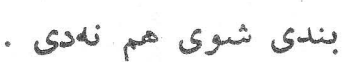

(نوربيا)

ميكاوى جم دانسان هـ

قالموس كم يـ تو دى دمبـه

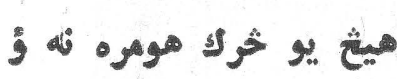

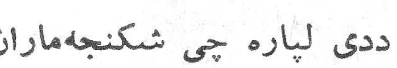

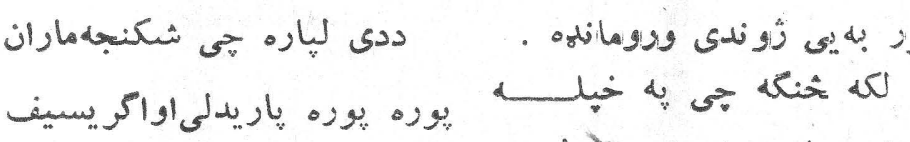

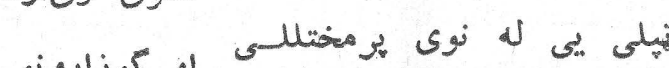

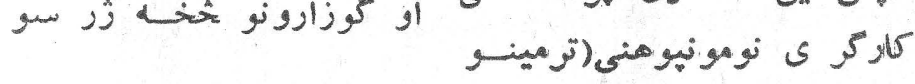

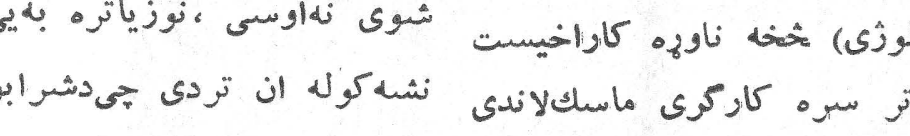

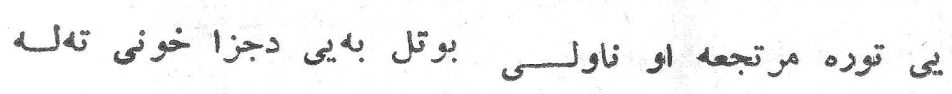

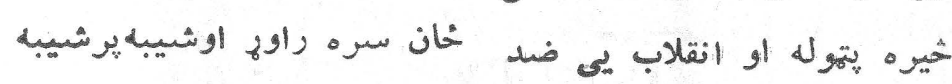

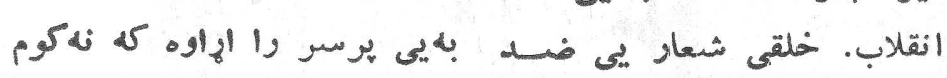

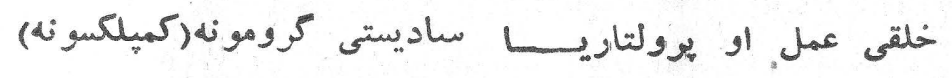

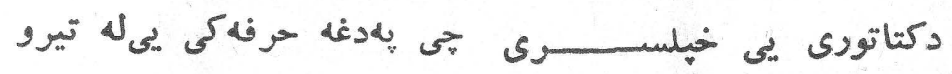

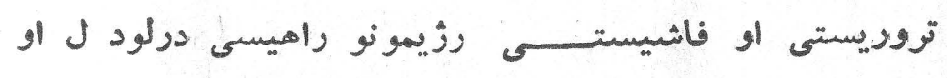

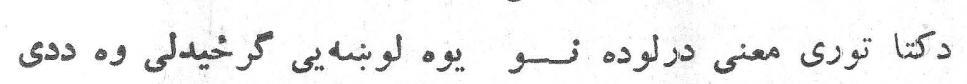

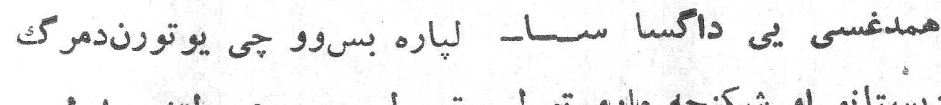

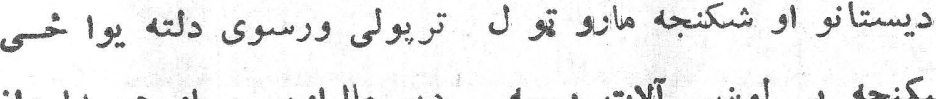

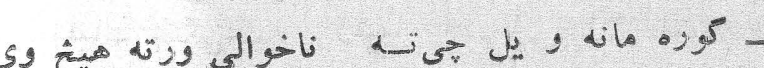

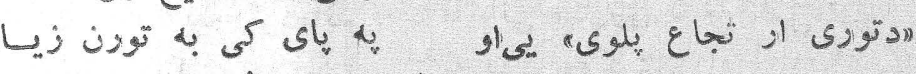

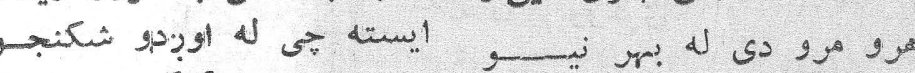

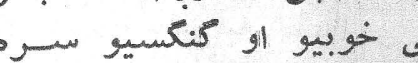

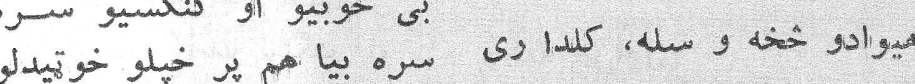

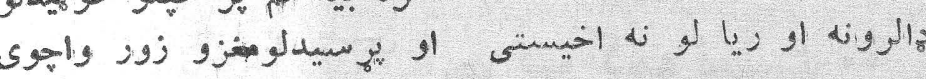

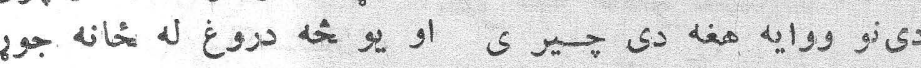

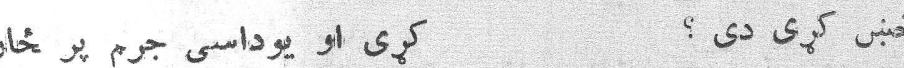

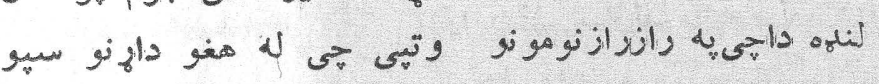

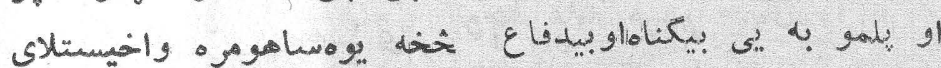

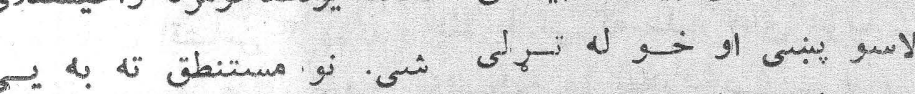

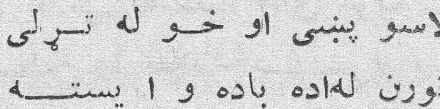

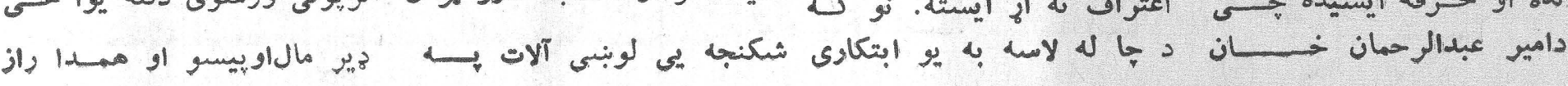




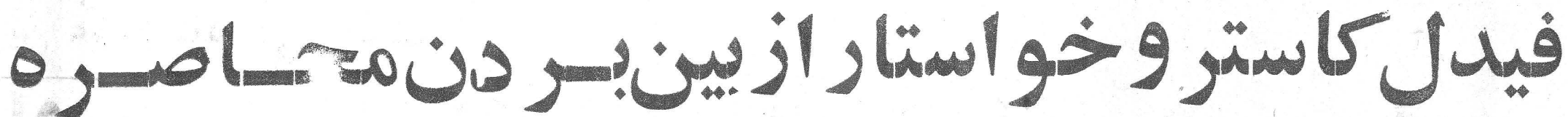

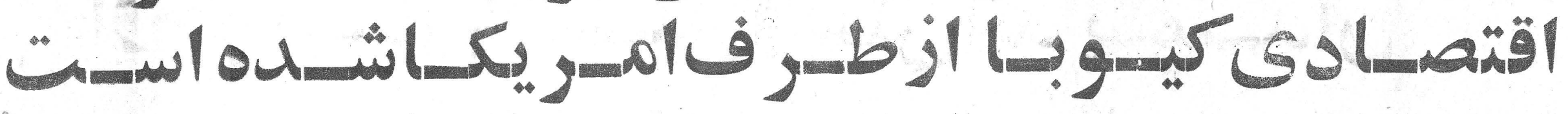

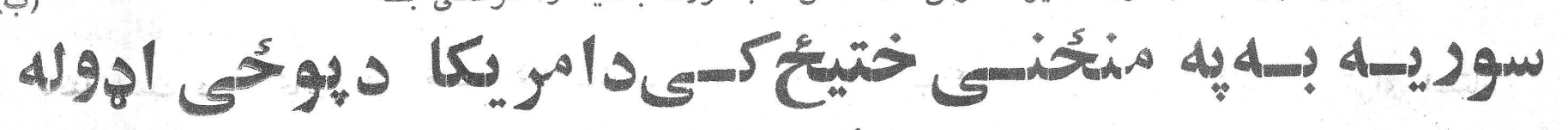

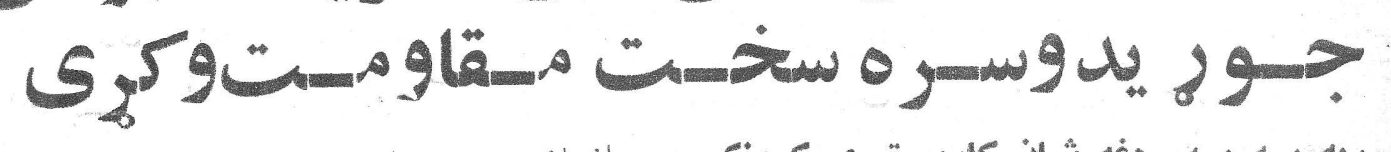

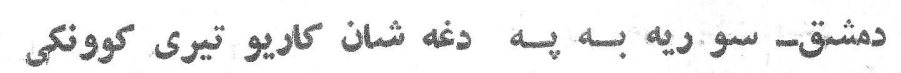

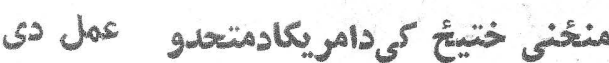

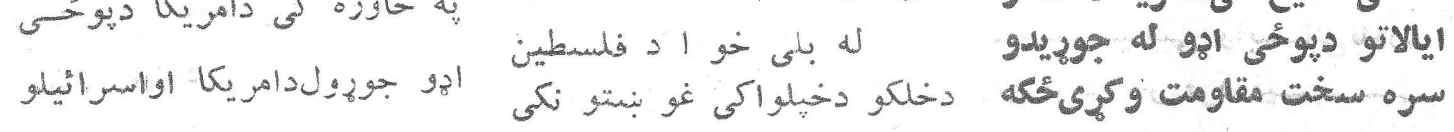

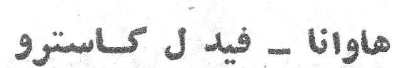

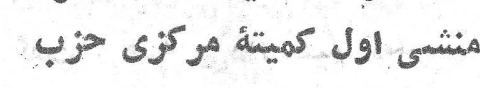

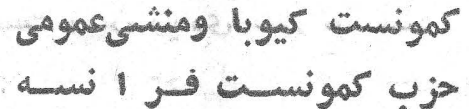

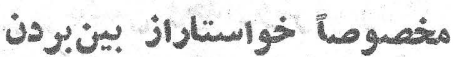

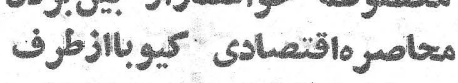

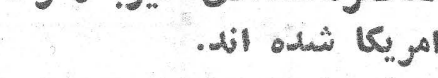

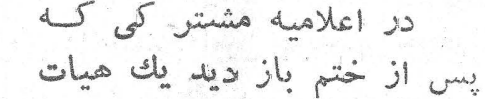

كنيت كاوندا وويل:

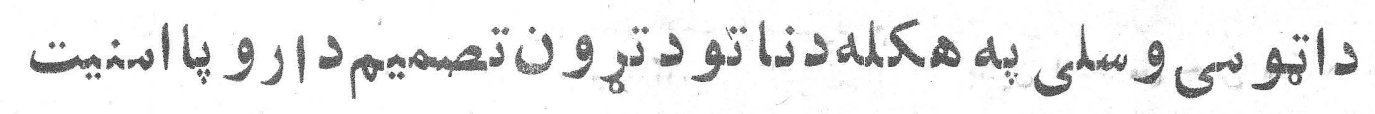

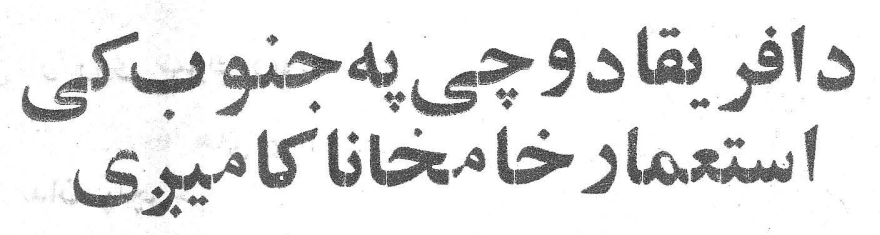
J

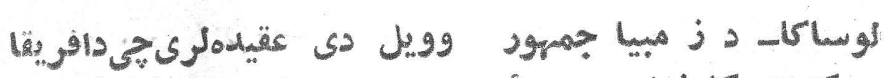

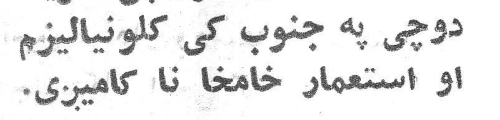

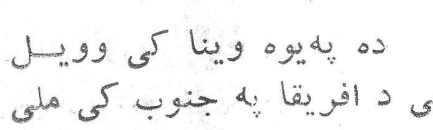

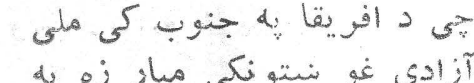

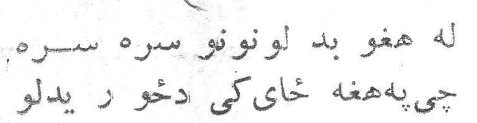

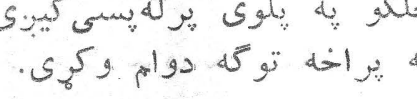

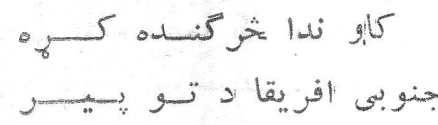

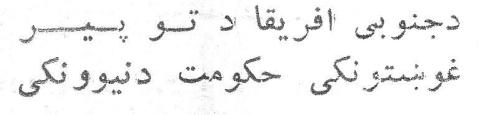

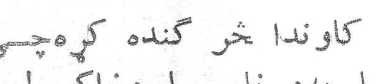

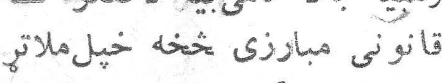

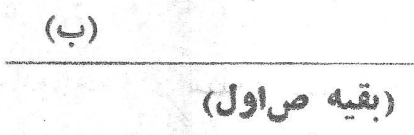

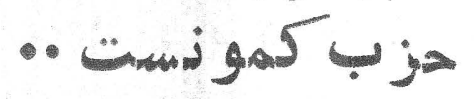

وا بدنام سازند بلكه ميخواهند

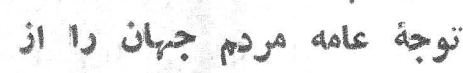

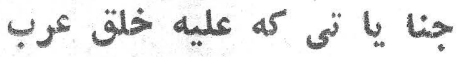

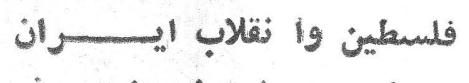

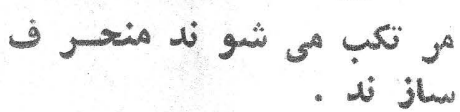

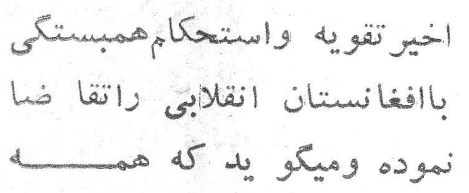

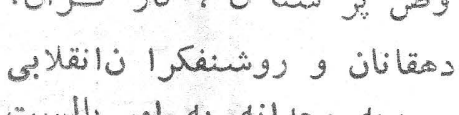

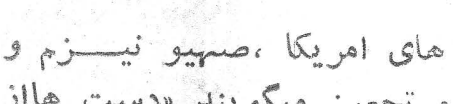

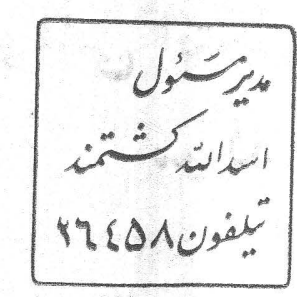

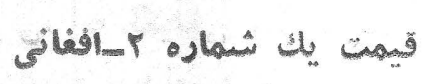

dratar ving 92

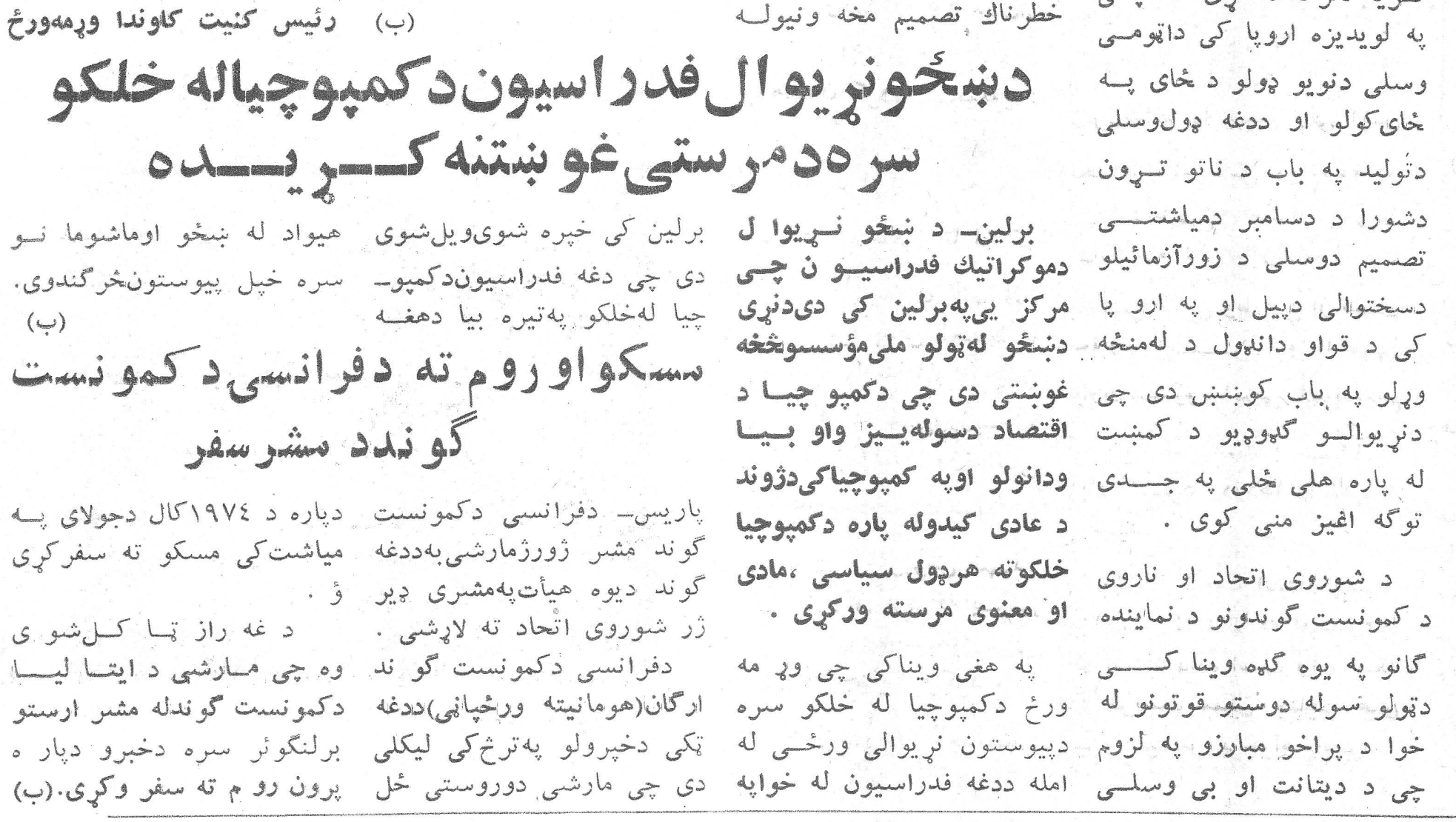

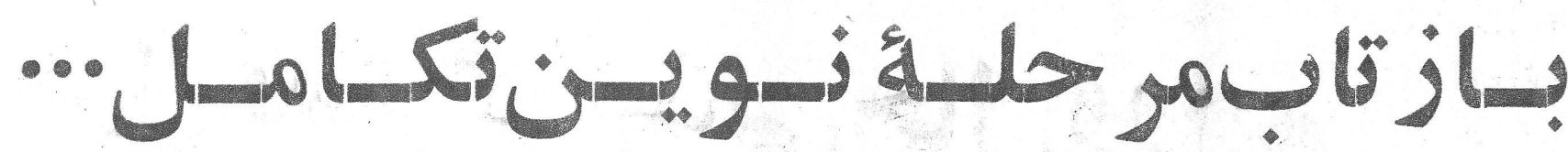

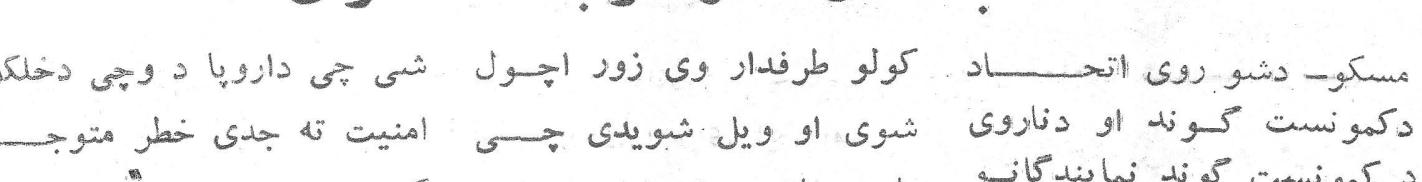

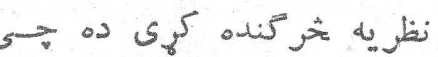

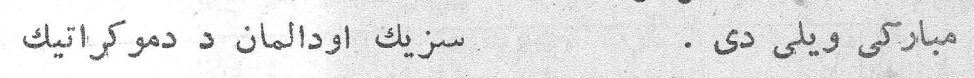

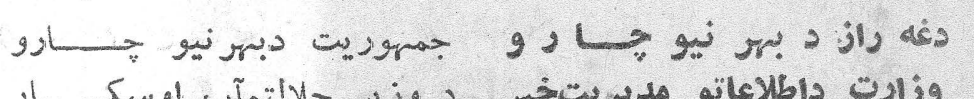

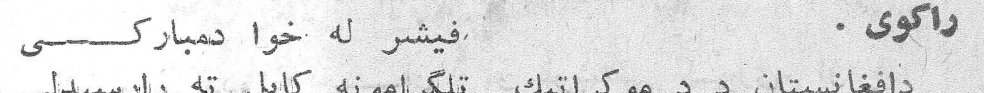

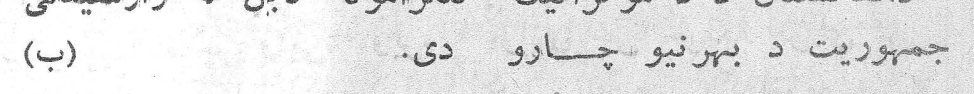

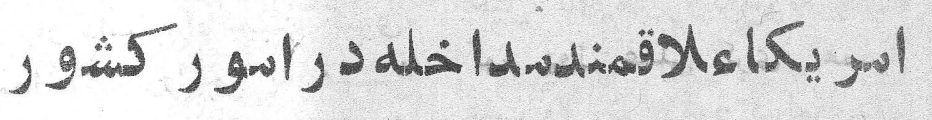

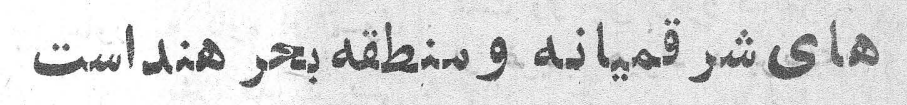

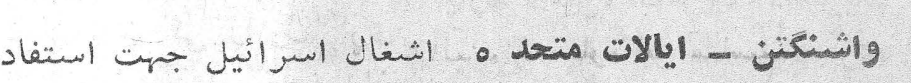

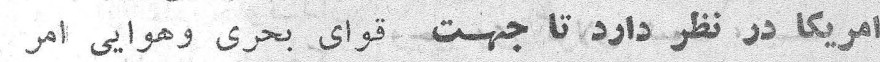

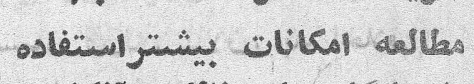
از بايكاه هاى نظظامى آنكثورد

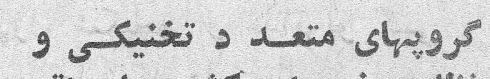

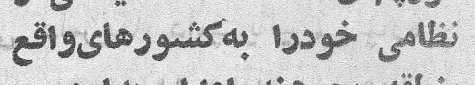

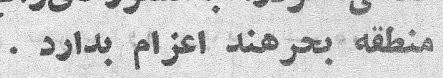
اين مطلب رايكنطاقوزارت

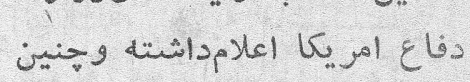

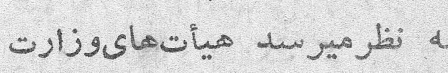

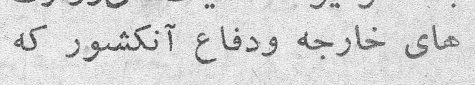

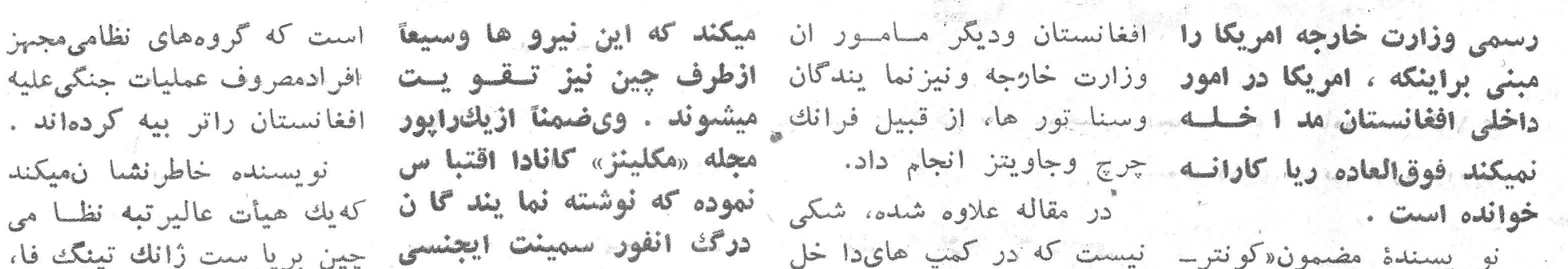

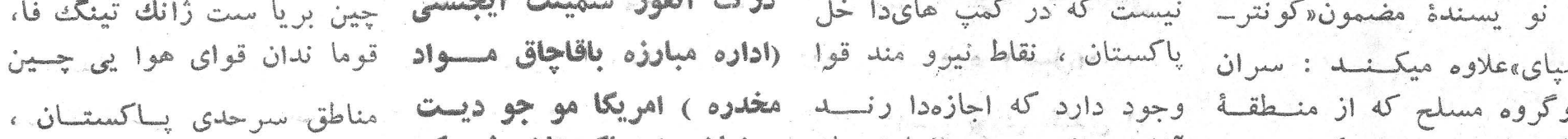

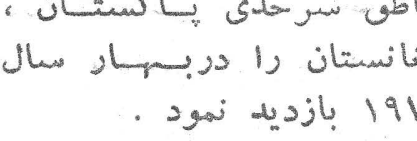

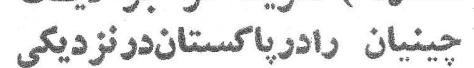

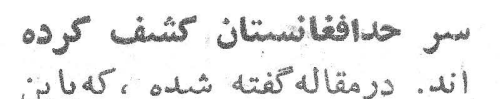

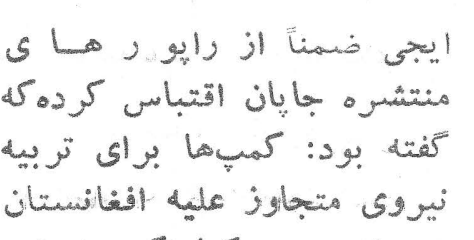

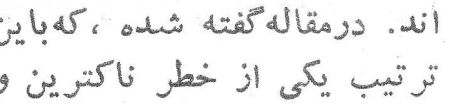

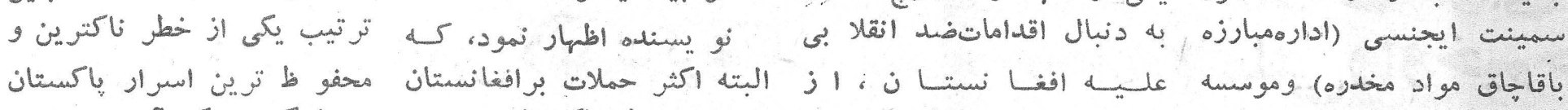

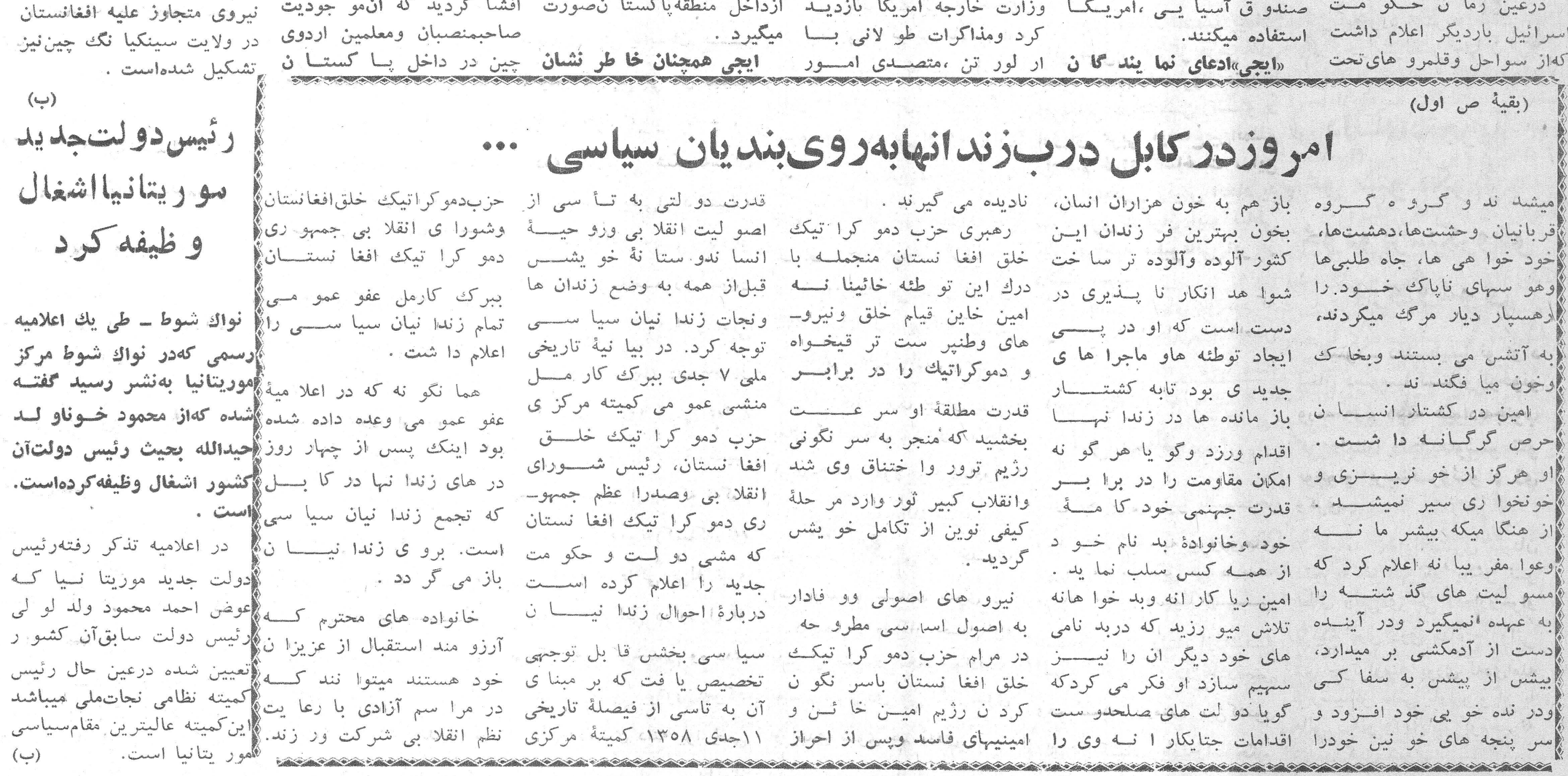

